\title{
Postnatal Day 2 to 11 Constitutes a 5-HT-Sensitive Period Impacting Adult mPFC Function
}

\author{
Tahilia J. Rebello, ${ }^{1}$ Qinghui Yu, ${ }^{1}$ Nathalie M. Goodfellow, ${ }^{2}$ Martha K. Caffrey Cagliostro, ${ }^{1}$ Anne Teissier, ${ }^{1}$ \\ Emanuela Morelli, ${ }^{1}$ Elena Y. Demireva, ${ }^{1}$ Alexei Chemiakine, ${ }^{1}$ Gorazd B. Rosoklija, ${ }^{1,3,4}$ Andrew J. Dwork, ${ }^{1,3,4}$ \\ (D) Evelyn K. Lambe, ${ }^{2}$ Jay A. Gingrich, ${ }^{1,3}$ and Mark S. Ansorge ${ }^{1,3}$ \\ ${ }^{1}$ Columbia University, New York, New York 10027, ${ }^{2}$ University of Toronto, Toronto, Ontario ON M5S 1A8, Canada, ${ }^{3}$ New York State Psychiatric Institute, \\ New York, New York 10032, and ${ }^{4}$ Macedonian Academy of Sciences and Arts, 1000 Skopje, Macedonia
}

Early-life serotonin [5-hydroxytryptamine (5-HT)] signaling modulates brain development, which impacts adult behavior, but 5-HTsensitive periods, neural substrates, and behavioral consequences remain poorly understood. Here we identify the period ranging from postnatal day 2 (P2) to P11 as 5-HT sensitive, with 5-HT transporter (5-HTT) blockade increasing anxiety-and depression-like behavior, and impairing fear extinction learning and memory in adult mice. Concomitantly, P2-P11 5-HTT blockade causes dendritic hypotrophy and reduced excitability of infralimbic (IL) cortex pyramidal neurons that normally promote fear extinction. By contrast, the neighboring prelimbic (PL) pyramidal neurons, which normally inhibit fear extinction, become more excitable. Excitotoxic IL but not PL lesions in adult control mice reproduce the anxiety-related phenotypes. These findings suggest that increased 5-HT signaling during P2-P11 alters adult mPFC function to increase anxiety and impair fear extinction, and imply a differential role for IL and PL neurons in regulating affective behaviors. Together, our results support a developmental mechanism for the etiology and pathophysiology of affective disorders and fear-related behaviors.

Key words: anxiety; development; mouse; prefrontal cortex; serotonin; SSRI

\section{Introduction}

Depression, pathological anxiety, and fear-related disorders often have their roots in development. For instance, developmental exposure to environmental factors can impact the vulnerability of an organism to affective and fear-related disorders later in life (Kendler et al., 1992; Caspi et al., 2003; Moffitt et al., 2007; Lupien et al., 2009; Bale et al., 2010). Furthermore, early-life anxiety levels are predictors of vulnerability to both anxiety and depression in adult humans (Parker et al., 1999; Weissman et al., 2005). These findings suggest that circuits regulating affective and fear behaviors are established early and are sensitive to perturbations occurring during their formation.

Early-life environmental manipulations that increase adult anxiety- and depression-like behaviors are associated with concomitant serotonin [5-hydroxytryptamine (5-HT)] signaling changes in

Received Feb. 25, 2013; revised July 22, 2014; accepted July 26, 2014.

Author contributions: T.J.R., O.Y., N.M.G., M.C.C., A.T., E.M., A.C., G.B.R., A.J.D., E.K.L., J.A.G., and M.S.A. designed research; T.J.R., Q.Y., N.M.G., M.C.C., A.T., E.M., E.Y.D., A.C., and M.S.A. performed research; G.B.R. and A.J.D. contributed unpublished reagents/analytic tools; T.J.R., Q.Y., N.M.G., M.C.C., A.T., E.M., E.K.L., and M.S.A. analyzed data; T.J.R., E.K.L., and M.S.A. wrote the paper

The work was supported by the Natural Sciences and Engineering Research Council of Canada (E.K.L.), a Tier II Canada Research Chair (E.K.L.), a Banting and Best Canada Graduate Scholarship from the Canadian Institutes of Health Research (N.M.G.), National Institute of Mental Health (J.A.G. and M.S.A.), and the Sackler Institute for Developmental Psychobiology (J.A.G. and M.S.A.). We thank C. Kellendonck and C. Teixeira for their critical review of the manuscript.

The authors declare no competing financial interests.

Correspondence should be addressed to Jay A. Gingrich, New York State Psychiatric Institute, 1051 Riverside Drive, New York, NY 10032. E-mail: jag46@columbia.edu.

DOI:10.1523/JNEUROSCI.1020-13.2014

Copyright $\odot 2014$ the authors $\quad 0270-6474 / 14 / 3412379-15 \$ 15.00 / 0$ brain regions that mediate affective behaviors, such as the medial prefrontal cortex (mPFC; Ansorge et al., 2007; Goodfellow et al., 2009, 2014; Leventopoulos et al., 2009; Oberlander et al., 2009; Benekareddy et al., 2010; Franklin et al., 2011; Rentesi et al., 2013; Ohta et al., 2014). Because 5-HT modulates neurodevelopmental processes during embryonic and early postnatal life (Gaspar et al., 2003), it has been hypothesized that such environmental and also 5-HTergic genetic factors impact adult behavior by altering the formation of anxiety, depression, and fear circuits (Gross et al., 2002; Ansorge et al., 2007; Homberg et al., 2010; Vitalis et al., 2013). Supporting this hypothesis and revealing a role for early postnatal 5-HT signaling in setting baseline anxiety and depression levels in adulthood, the affective phenotype of constitutive 5-htt-, maoa-, or htrla-deficient mice is reproduced by blocking the function of these molecules solely during the first weeks of life (Ansorge et al., 2004, 2008; Lo Iacono and Gross, 2008; Vinkers et al., 2010; Yu et al., 2014). These data mechanistically bridge the role of 5-HT-related environmental and genetic factors in influencing brain development pertaining to emotional function, and imply that drugs targeting the 5-HT system might exert adverse consequences during sensitive developmental periods (Oberlander et al., 2009).

To increase insight into the 5-HT-sensitive developmental period underlying early-life programming of anxiety- and depression-like behaviors, we first sought to better define its temporal aspects. Because of the convergence between $\mathrm{mPFC}$ dysfunction leading to depressed mood (Mayberg et al., 1999; Fujioka et al., 2004; Adhikari et al., 2011; Warden et al., 2012) and 
Table 1. Experimental cohort used to narrow down the 5-HT-sensitive developmental time window

\begin{tabular}{|c|c|c|c|c|c|c|c|c|c|c|}
\hline Experimental cohort & Treatment & Time & Animals & Males & Females & Litter & Mice per litter & Male mice per litter & Female mice per litter & Females/total \\
\hline \multirow{24}{*}{$\begin{array}{l}\text { Sensitive period, } \\
\text { OF, NSF, SESC (Fig. 1) }\end{array}$} & VEH & P2-P21 & 20 & 10 & 10 & A & 6 & 3 & 3 & 0.50 \\
\hline & VEH & P2-P21 & & & & B & 5 & 2 & 3 & 0.60 \\
\hline & VEH & P2-P21 & & & & C & 5 & 2 & 3 & 0.60 \\
\hline & FLX & P2-P21 & 20 & 11 & 9 & A & 6 & 4 & 2 & 0.33 \\
\hline & FLX & P2-P21 & & & & B & 5 & 5 & 0 & 0.00 \\
\hline & FLX & P2-P21 & & & & C & 4 & 1 & 3 & 0.75 \\
\hline & VEH & P2-P11 & & & & B & 6 & 3 & 3 & 0.50 \\
\hline & VEH & P2-P11 & & & & C & 6 & 3 & 3 & 0.50 \\
\hline & VEH & P2-P11 & & & & D & 6 & 4 & 2 & 0.33 \\
\hline & FLX & P2-P11 & 23 & 11 & 12 & A & 5 & 2 & 3 & 0.60 \\
\hline & FLX & P2-P11 & & & & B & 5 & 2 & 3 & 0.60 \\
\hline & FLX & P2-P11 & & & & C & 4 & 3 & 1 & 0.25 \\
\hline & VEH & P12-P21 & & & & $C$ & 5 & 4 & 1 & 0.20 \\
\hline & VEH & P12-P21 & & & & D & 4 & 3 & 1 & 0.25 \\
\hline & FLX & P12-P21 & 23 & 11 & 12 & $A$ & 8 & 3 & 5 & 0.63 \\
\hline & FLX & P12-P21 & & & & B & 5 & 2 & 3 & 0.60 \\
\hline & FLX & P12-P21 & & & & C & 6 & 3 & 3 & 0.50 \\
\hline & FLX & P12-P21 & & & & D & 3 & 2 & 1 & 0.33 \\
\hline & VEH & P22-P41 & 19 & 12 & 7 & A & 7 & 3 & 4 & 0.57 \\
\hline & VEH & P22-P41 & & & & B & 6 & 5 & 1 & 0.17 \\
\hline & VEH & P22-P41 & & & & C & 6 & 4 & 2 & 0.33 \\
\hline & FLX & P22-P41 & 24 & 13 & 11 & A & 7 & 4 & 3 & 0.43 \\
\hline & FLX & P22-P41 & & & & B & 7 & 3 & 4 & 0.57 \\
\hline & FLX & P22-P41 & & & & C & 5 & 3 & 2 & 0.40 \\
\hline
\end{tabular}

$5-h t t^{-/-}$mice as well as carriers of the 5-HTTLPR " $s$ " allele displaying structural and functional alterations in the MPFC (Heinz et al., 2005; Pezawas et al., 2005; Wellman et al., 2007; Frodl et al., 2008; Roiser et al., 2009; Shah et al., 2009; Atmaca et al., 2011; Kobiella et al., 2011; Lemogne et al., 2011), we next studied the consequences of postnatal 5-HT transporter (5-HTT) blockade on morphological and electrophysiological properties in the $\mathrm{mPFC}$, and probed $\mathrm{mPFC}$-sensitive fear extinction and extinction recall behaviors. Last, to test whether altered mPFC function could underlie the increased anxiety- and depression-like phenotype of mice that experienced increased postnatal 5-HT signaling, we investigated the emotional behavioral consequences of subregion-specific excitotoxic mPFC lesions.

\section{Materials and Methods}

\section{Subjects}

129S6/SvEvTac mice were used for all experiments. These mice demonstrate higher levels of anxiety compared with outbred mice (Rodgers et al., 2002), and are particularly vulnerable to the effects of chronic social stress (Dadomo et al., 2011). Thus, this mouse line is particularly suitable to study anxiety- and depression-related behaviors. Conversely, it is possible that behavioral effects studied here might not be detected when using more stress-resilient background strains.

We used male and female mice for most of our experiments (Tables 1, 2 ). We did not detect an interaction between gender and any dependent variable in our tests, and therefore only show the collapsed data in our figures. However, we do not emphasize this negative finding, because our experiments were not designed to thoroughly investigate the effect of gender. For example, many difference between males and females are dependent upon the estrous cycle (Frye et al., 2000; Marcondes et al., 2001; Gouveia et al., 2004), which we did not control for in our experiments. Thus, our experimental designs limit our ability to claim that gender does not influence our experimental readouts, and our negative results should be interpreted in this context.

For postnatally treated cohorts, male and female wild-type $129 \mathrm{SvEv}$ mice received daily intraperitoneal injections with either vehicle (VEH; $0.9 \% \mathrm{NaCl}, 5 \mathrm{ml} / \mathrm{kg}$ ) or fluoxetine (FLX; $10 \mathrm{mg} / \mathrm{kg}$ in $\mathrm{VEH}, 5 \mathrm{ml} / \mathrm{kg}$ ). Multiple cohorts of mice were created for the various experiments (Tables 1,2$)$. The largest cohort was created to investigate the sensitivity to 5-HTT blockade of multiple developmental periods (Table 1). To create this cohort, mice received daily injections with either FLX or VEH during one of the following time windows: postnatal day 2 (P2)-P21, P2-P11, $\mathrm{P} 12-\mathrm{P} 21, \mathrm{P} 22-\mathrm{P} 41$ (creating eight groups in total; Table 1). The P2-P21 treatment epoch served as a positive control. The shorter P2-P11 and $\mathrm{P} 12-\mathrm{P} 21$ treatment groups served to test the hypothesis that a narrower sensitive period exists. A postweaning-treated group (P22-P41) was used to control for the epoch specificity of behavioral effects. Behavioral testing was performed starting at P90.

Smaller cohorts were used to test specific hypotheses pertaining to the consequences of 5-HTT blockade only during P2-P11 (Table 2). Finally, two cohorts were created that tested the impact of excitotoxic lesions on behavior (Table 2). For preweaning treatments, entire litters were removed from dams and placed into a bucket $(10 \mathrm{~cm}$ diameter $)$ containing bedding from the respective home cage. The bucket was placed on a scale to allow measurement of the weight of a pup, when removing it for injection. Mice were injected in chance order and immediately placed back in the home cage. An entire litter was injected within $2 \mathrm{~min}$, and pups were observed after injections to ensure they were being attended to by their dams. Mice were generated by synchronized breeding, and only 
Table 2. Overview of experimental cohorts used to study the P2-P11 period and the effect of mPFC lesions

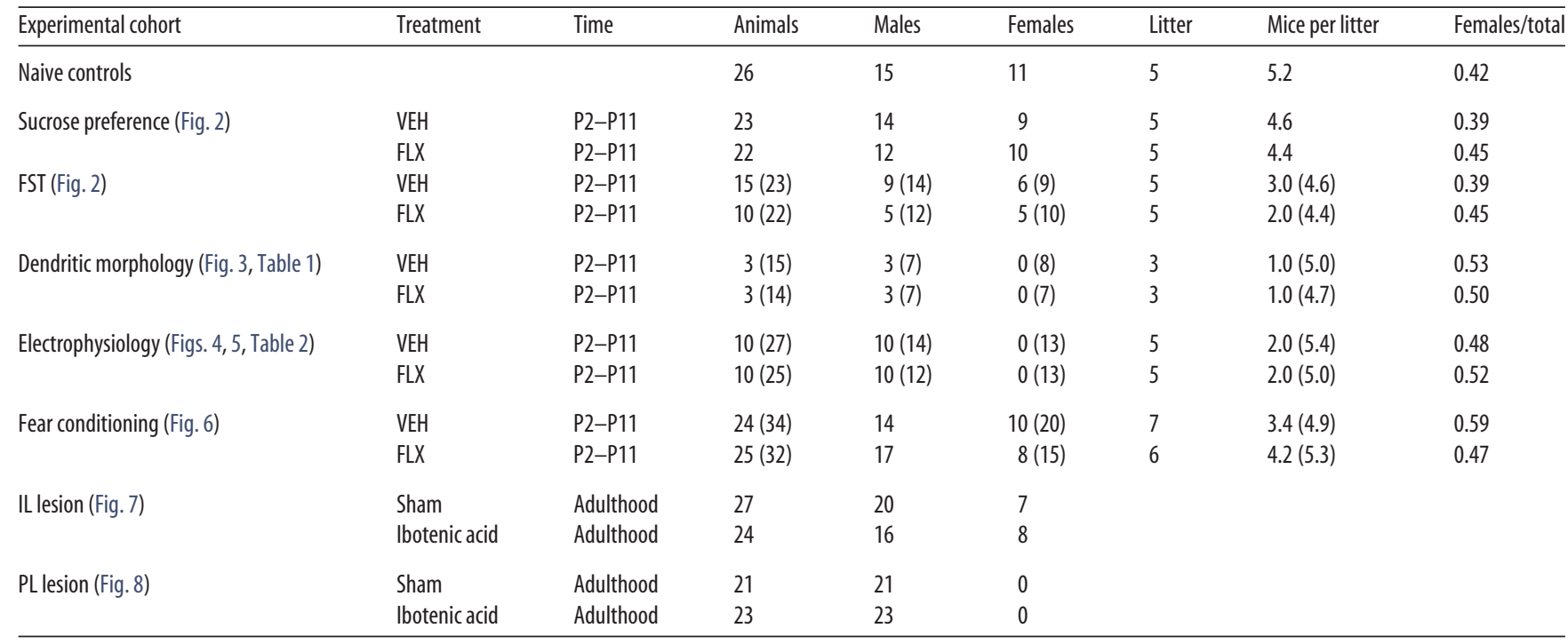

Numbers in parentheses refer to animals generated and are shown if only a subset of these animals were used in experiments.

litters of three to eight mice were used to generate experimental cohorts (larger or smaller litters were not culled but were used for unrelated purposes). The average number of pups per litter in the different cohorts varied between 4.4 and 5.4 (Tables 1,2). The average sex composition in the different cohorts varied between $39 \%$ and $59 \%$ females (Tables 1, 2). Mice were housed in the same room and rack, and were weaned and ear tagged on P21. Studying the effect of postnatal VEH (PN-VEH) versus PN-FLX exposure previously, we had assigned all pups within a litter either to the same treatment (Ansorge et al., 2004) or to different treatments (Ansorge et al., 2008) and had observed comparable effects between studies. Assigning different pups within a litter to different treatment conditions requires the unique identification of individual pups, for example through tattooing their paws (Ansorge et al., 2008). However, because we did not previously notice an effect of differentially treating within versus between litters and because we aimed at keeping the degree of litter interference as minimal as possible, we here decided to assign all mice within a litter the same treatment condition. Treatment conditions were assigned in alternating order and balancing litter sizes. After weaning, mice were separated by sex and housed in groups of five mice. For nontreated (naive) control mice, entire litters in the same breeding cohort were left noninjected and nonhandled except for weekly cage changing. Naive mice were used as a second control to investigate whether postnatal handling and injecting impacted adult behavior. For example, it is possible that early postnatal handling and treatment affects pup behavior, which could in turn alter maternal behavior during the preweaning phase (Hofer and Shair, 1978; Kuhn and Schanberg, 1998). In the classic studies, dams separated from their pups engage in heightened levels of maternal behaviors such as grooming and nursing upon reunion (Lee and Williams, 1974; Liu et al., 1997), which are associated with long-term decreases in offspring stress responses and reduced behavioral fearfulness (Rosenberg et al., 1970; Liu et al., 1997; Caldji et al., 1998).

Animals were housed such that each cage contained mice that received different postnatal treatments. All animals were maintained on a $12 \mathrm{~h}$ light/dark cycle, and were provided with food and water ad libitum, except as noted. Animal testing was conducted in accordance with the principles of the Guide for the Care and Use of Laboratory Animals from the National Institute of Health and the Institutional Animal Care and Use Committee guidelines.

\section{Behavioral testing}

Behavioral testing was conducted on mice age P90 and above. For cohorts that received multiple testing, the tests were administered in the following order: open field (OF), novelty-suppressed feeding (NSF), and shock escape (SESC) with a minimum intertest duration of $7 \mathrm{~d}$.
Open field. Measurement of exploratory activity in response to a novel environment was assessed as previously described (Ansorge et al., 2008) using the open field test. Briefly, mice were allowed to explore brightly lit (800-900 lux) Plexiglas activity chambers $[43.2 \times 43.2 \times 30.5 \mathrm{~cm}$ (length $\times$ width $\times$ height); model ENV-520, Med Associates] equipped with infrared beams to detect both horizontal and vertical motion. Mice were placed in the center of the chamber and were allowed to freely explore for $60 \mathrm{~min}$. Testing was done in bright-light conditions (800-900 lux). Total ambulatory time, total time in the center (defined as the central $15 \times 15 \mathrm{~cm}$ region) and vertical activity (rearing) were measured.

Novelty-suppressed feeding. The novelty-suppressed feeding test was performed as previously described (Ansorge et al., 2008). First, mice were food deprived for $24 \mathrm{~h}$ with water available ad libitum. Food-deprived mice were then removed from their home cage and placed in a holding cage for $30 \mathrm{~min}$ before the test. For testing, mice were placed in the corner of a brightly lit ( $800-900$ lux $)$ open arena $(51 \times 35 \mathrm{~cm})$ containing clean wood chip bedding and a white filter paper $125 \mathrm{~mm}$ in diameter placed in the center of the arena, with two familiar food pellets together weighing $\sim 4 \mathrm{~g}$ attached to the paper. The latency to approach the pellet and begin a feeding episode was recorded (maximum time was $10 \mathrm{~min}$ ). Immediately after initiating a feeding episode, mice were removed from the arena and placed into another holding cage, which was used to transfer mice to an adjacent room for weighing and home-cage food consumption testing. Home-cage food consumption was assessed by placing mice into their home cage containing a preweighed food pellet and allowing them to feed freely for $5 \mathrm{~min}$. Food consumption was determined by the difference in the weight of the pellet. Mice for all conditions were weighed the day before food deprivation and again after the latency test (before home-cage feeding) to calculate the percentage of weight loss.

Shock escape. The shock escape test was performed as previously described (Ansorge et al., 2008). Briefly, mice were tested in a Plexiglas box (model ENV 010MD, Med Associates) located within a soundattenuated chamber. The box was divided into two identical chambers $[20 \times 17 \times 20 \mathrm{~cm}$ (length $\times$ width $\times$ height $)]$ and separated by an automated guillotine door. The apparatus was equipped with a grid floor made of stainless steel beams and connected to a shock generator, and eight infrared beams for detecting movement of the animal. Mice were placed into the chamber with the guillotine door raised and were allowed to freely explore both compartments for $5 \mathrm{~min}$ after which the guillotine door closed and the trials commenced. At the beginning of each trial, the door was raised and a mild scrambled footshock $(0.2 \mathrm{~mA} ; 10 \mathrm{~s}$ maximum duration) was delivered to the subject. The end of a trial was signaled by the closing of the guillotine door and was triggered either by a transition to the opposite chamber ("escape") or after 10 s. The test consisted of 30 
Table 3. Statistical data for gender interaction analyses

\begin{tabular}{|c|c|c|c|c|c|c|c|c|}
\hline \multirow{3}{*}{$\begin{array}{l}\text { Experiments } \\
\text { Sensitive period }\end{array}$} & \multirow{3}{*}{$\begin{array}{l}\text { Test } \\
\text { OF }\end{array}$} & \multirow{2}{*}{ Dependent measure } & \multicolumn{6}{|c|}{ Gender interactions } \\
\hline & & & \multicolumn{2}{|l|}{ Gender $\times$ time } & \multicolumn{2}{|c|}{ Gender $\times$ treatment } & \multicolumn{2}{|c|}{ Gender $\times$ time $\times$ treatment } \\
\hline & & Ambulkatory time & $F_{(3,147)}=2.550$ & $p=0.058$ & $F_{(1,147)}=0.024$ & $p=0.8772$ & $F_{(3147)}=1.776$ & $p=0.1542$ \\
\hline & & Time spent rearing & $F_{(3,147)}^{(3,14 /)}=0.867$ & $p=0.46$ & $F_{(1,147)}^{(1,4 /)}=1.707$ & $p=0.1935$ & $F_{(3,147)}=1.399$ & $p=0.2454$ \\
\hline & & Time in center & $F_{(3,147)}^{(3,14 /)}=0.944$ & $p=0.421$ & $F_{(1,147)}^{(1,14 /)}=0.719$ & $p=0.3979$ & $F_{(3,147)}^{(3,4 / 1)}=0.375$ & $p=0.7709$ \\
\hline & NSF & Latency to feed & $F_{(3,154)}^{(3,14)}=0.521$ & $p=0.6683$ & $F_{(1,154)}^{(1,14 /)}=0.247$ & $p=0.6198$ & $F_{(3,154)}^{(3,14)}=2.145$ & $p=0.0968$ \\
\hline & SESC & Latency to escape & $F_{(3,153)}=0.207$ & $p=0.8912$ & $F_{(1,153)}=0.32$ & $p=0.5726$ & $F_{(3,153)}=1.777$ & $p=0.154$ \\
\hline & & Intratrial activity & $F_{(3,153)}=0.581$ & $p=0.6286$ & $F_{(1,153)}=0.155$ & $p=0.6939$ & $F_{(3,153)}=0.879$ & $p=0.4535$ \\
\hline \multirow[t]{7}{*}{ PNVEH $_{(P 2-11)}$ VS PNFLX $_{(P 2-11)}$} & SPT & Sucrose consumption & & & $F_{(1,41)}=0.513$ & $p=0.4779$ & & \\
\hline & & Water consumption & & & $F_{(1,41)}=2.984$ & $p=0.0916$ & & \\
\hline & & Weight & & & $F_{(1,41)}=1.844$ & $p=0.1819$ & & \\
\hline & FST & Time floating & & & $F_{(1,21)}=0.222$ & $p=0.6425$ & & \\
\hline & $\mathrm{CFC}$ & Extinction training (D1) & & & & & $F_{(5,225)}=1.707$ & $p=0.134$ \\
\hline & & Post-tone freezing (D1) & & & $F_{(1,45)}=0.337$ & $p=0.5646$ & & \\
\hline & & Extinction learning/recall & & & & & $F_{(4,156)}=1.061$ & $p=0.3777$ \\
\hline \multirow[t]{6}{*}{ IL lesioning } & $\mathrm{OF}$ & Ambulatory time & & & $F_{(1,47)}=0.324$ & $p=0.5721$ & & \\
\hline & & Time spent rearing & & & $F_{(1,47)}=0.109$ & $p=0.7427$ & & \\
\hline & & Time in center & & & $F_{(1,47)}=1.659$ & $p=0.204$ & & \\
\hline & NSF & Latency to feed & & & $F_{(1,46)}=0.801$ & $p=0.3753$ & & \\
\hline & SESC & Latency to escape & & & $F_{(1,46)}=0.653$ & $p=0.4232$ & & \\
\hline & & Intratrial activity & & & $F_{(1,46)}=0.002$ & $p=0.9671$ & & \\
\hline
\end{tabular}

CFC, Cued fear conditioning.

trials separated by a $30 \mathrm{~s}$ intertrial interval (ITI). Latencies to escape for each trial were recorded. If the subject failed to make a transition during the $10 \mathrm{~s}$ duration of the footshock, a maximum latency of $10 \mathrm{~s}$ was recorded. Locomotor activity was assessed during intershock intervals by counting the total number of infrared beam interruptions during each session.

Sucrose preference test. Mice were trained as groups in their home cage for 2 nights to drink from two serological pipettes with sippers attached. One pipette contained water, and the other one contained $2 \%$ sucrose diluted in water. The position of the two pipettes was reversed on night 2 to prevent spatial bias. Testing occurred on night 3 with mice individually housed in cages containing home-cage bedding. The volume of liquid consumed from both pipettes was recorded over a $2 \mathrm{~h}$ period (7:00 to 9:00 P.M.). The relative position of the pipettes was alternated throughout the testing cages. During training and testing, the two pipettes provided the only drinking source.

Forced swim test. The forced swim test (FST) was performed as previously described (Holick et al., 2008). Briefly, mice were put into a $4 \mathrm{~L}$ beaker containing $2.2 \mathrm{~L}$ of $26^{\circ} \mathrm{C}$ water for 6 min on 2 consecutive days. Mobility was measured through videotracking (VideoTrack software, ViewPoint). Data for the second day are presented. After each test, mice were dried in a paper-containing cage, which was warmed by a heat lamp.

Fear conditioning and extinction. Mice were fear conditioned using an equipment setup that was similar to that previously described (Drew et al., 2010). For all sessions, mice were recorded using a video camera mounted above the conditioning chamber, and movement was monitored using FreezeFrame software (Actimetrics). The percentage of freezing was calculated using FreezeView software (Actimetrics). Freezing was defined as the cessation of all movement, excluding respiration, and the freezing bout duration was defined as $0.5 \mathrm{~s}$. On day 1 (D1), mice were placed into the conditioning chamber (context A; ENV010MD, Med Associates), allowed to explore freely for $180 \mathrm{~s}$, and then received three tone-shock pairings, with variable ITIs, in which each $20 \mathrm{~s}, 80 \mathrm{~dB}, 2000$ $\mathrm{Hz}$ tone coterminated with a $2 \mathrm{~s}, 0.75 \mathrm{~mA}$ scrambled footshock. On D2, mice received a second day of cued fear conditioning (two tone-shock pairings: $20 \mathrm{~s}, 80 \mathrm{~dB}, 2000 \mathrm{~Hz}$ tone; $2 \mathrm{~s}, 0.75 \mathrm{~mA}$ shock; $20 \mathrm{~s}$ ITI, in context A). On D3 and D4, mice underwent cued fear extinction training in novel context $\mathrm{B}$, which differed significantly from conditioning context A [distinct odor cues, wall color/composition, floor composition (grid floor vs bedding) and room/chamber lighting]. During extinction training sessions, mice were placed in context $\mathrm{B}$, were allowed to explore freely, and were then presented with 30 tones $(20 \mathrm{~s}, 80 \mathrm{~dB}, 2000 \mathrm{~Hz} ; 5 \mathrm{~s}$ ITI; $30 \mathrm{~s}$ post-tone period; $955 \mathrm{~s}$ total session time). On day 5 , mice were placed back into context $\mathrm{B}$, and their freezing response to five tones $(20 \mathrm{~s}, 80 \mathrm{~dB}$,
$2000 \mathrm{~Hz}, 5$ s ITI; 305 s total session time) was measured. When indicated, percentage freezing values were normalized to freezing levels at the start of the extinction session (D3 start).

\section{Analysis of dendritic complexity}

Brains from adult ( $>$ P90), male PN-VEH and PN-FLX mice were processed with the Golgi stain, as previously described (Scobie et al., 2009; Rosoklija et al., 2014). We used only male mice to reduce variance. Stained brains were then cut using a vibratome to generate $150 \mu \mathrm{m}$ sections, which were mounted on slides. Pyramidal neurons $(n=4-5$ per mouse) in the infralimbic (IL) and prelimbic (PL) regions (layer II/III) were visualized at $100 \times$ magnification and manually traced using Neurolucida software (MBF Bioscience). The criteria for cell selection were as previously described (Scobie et al., 2009). The extent of dendritic arborization was determined via Sholl analysis (Sholl, 1953) using NeuroExplorer software (MBF Bioscience). Dependent measures from the Sholl analysis output included the number of nodes (branch points), intersections (number of branches crossing through a specified segment of dendritic tree), total dendritic material, and length of the dendritic tree (distance between the soma and the farthest point of the dendritic tree). The brain sections were coded so that the observer was blind to treatment conditions.

\section{Electrophysiology}

Acute coronal brain slices ( $400 \mu \mathrm{m}$ thick) were obtained from the prefrontal cortex (2.46-1.34 mm from bregma) of male PN-VEH and PNFLX mice (treated P2-P11, as described above). We used only male mice to reduce variance. Excised brains were rapidly cooled with $4^{\circ} \mathrm{C}$ oxygenated sucrose artificial CSF (ACSF; $254 \mathrm{~mm}$ sucrose was substituted for $\mathrm{NaCl}$ ), cut on a D.S.K. LinearSlicer (SciMedia), and transferred to $30^{\circ} \mathrm{C}$ oxygenated ACSF (128 mm NaCl, $10 \mathrm{~mm}$ D-glucose, $26 \mathrm{~mm} \mathrm{NaHCO}_{3}, 2$ $\mathrm{mm} \mathrm{CaCl}_{2}, 2 \mathrm{mM} \mathrm{MgSO}_{4}, 3 \mathrm{~mm} \mathrm{KCl}, 1.25 \mathrm{~mm} \mathrm{NaH}_{2} \mathrm{PO}_{4}, \mathrm{pH}$ 7.4). After a recovery period $(>1-2 \mathrm{~h})$, slices were placed in a superfusion chamber on the stage of an Olympus BX50WI microscope. Slices were immersed in regular bubbled ACSF ( $95 \%$ oxygen and $5 \%$ carbon dioxide; $31-33^{\circ} \mathrm{C}$ ) that flowed at a rate of 3-4 $\mathrm{ml} / \mathrm{min}$. Whole-cell recordings from layer II/III pyramidal neurons in the IL and PL regions of medial prefrontal cortex were performed using electrodes (3-4 M $\Omega$ ) containing $120 \mathrm{mM}$ potassium gluconate, $5 \mathrm{~mm} \mathrm{KCl,} 2 \mathrm{~mm} \mathrm{MgCl}_{2}, 4 \mathrm{~mm} \mathrm{~K}_{2}$-ATP, $0.4 \mathrm{~mm}$ $\mathrm{Na}_{2}$-GTP, $10 \mathrm{~mm} \mathrm{Na} \mathrm{Na}_{2}$-phosphocreatine, and $10 \mathrm{~mm}$ HEPES buffer, adjusted to $\mathrm{pH} 7.3$ with $\mathrm{KOH}$. Membrane excitability was recorded using a Multiclamp 700b amplifier (Molecular Devices) and measured by the number of action potentials evoked by each $500 \mathrm{~ms}$ depolarizing current pulse ranging from 0 to $450 \mathrm{pA}$ at $50 \mathrm{pA}$ increments with an intertrial interval of $1 \mathrm{~s}$. 
A

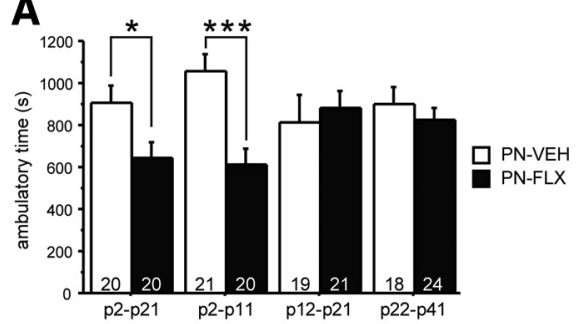

D

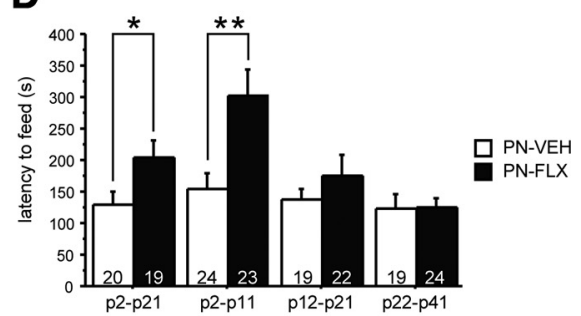

G

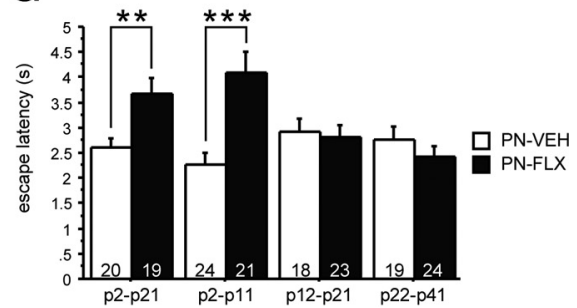

B

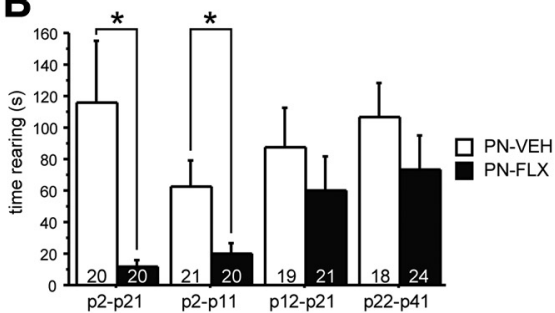

E

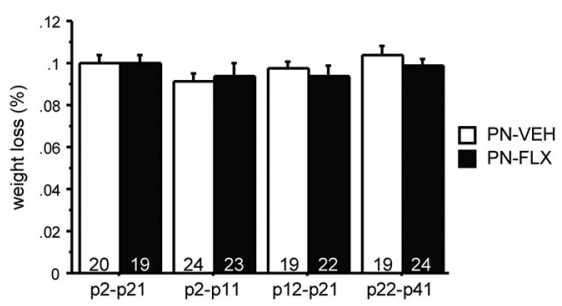

H

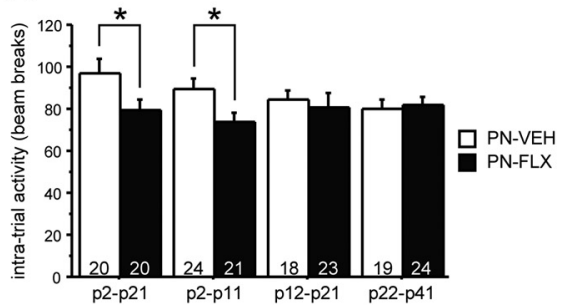

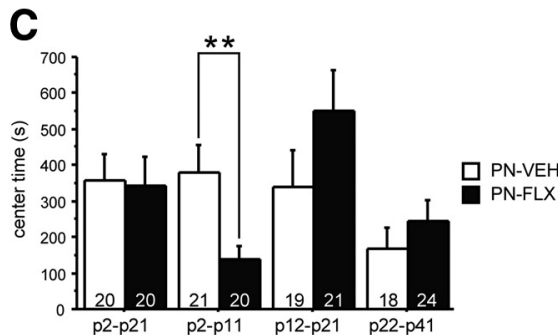

$\mathbf{F}$

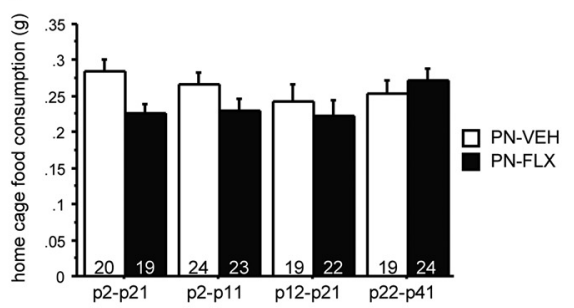

I

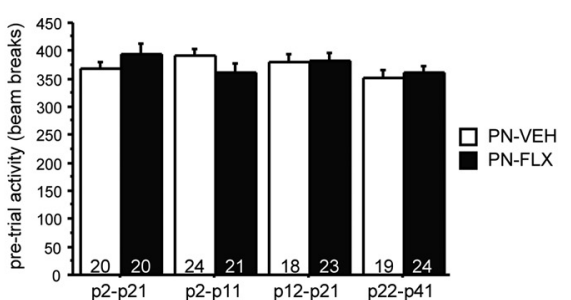

Figure 1. PN-FLX treatment from either $P 2$ to $P 21$ or $P 2$ to $P 11$ enhances anxiety and depression-like behaviors in adult mice. $\boldsymbol{A}-\boldsymbol{C}$, In the novel $0 F$ test, FLX treatment from $P 2$ to $P 21$ or $P 2$ to $P 11$ results in significantly reduced time ambulating $(\boldsymbol{A})$ and rearing $(\boldsymbol{B})$; FLX treatment from P2 to P11 also results in significantly reduced time in the center region of the chamber $(\boldsymbol{C})$. $\boldsymbol{D}-\boldsymbol{F}$, In the NSF test, FLX treatment from P2 to P21 or P2 to P11 significantly increases the latency to feed $(\boldsymbol{D})$, while the percentage weight loss after $24 \mathrm{~h}$ food deprivation $(\boldsymbol{E})$ and home-cage food consumption $(\boldsymbol{F})$ are not affected by treatment. $\mathbf{G}-\boldsymbol{I}$, In the SESC test, FLX treatment from P2 to P21 or P2 to P11 results in significantly increased latency to escape $(\boldsymbol{G})$ and suppressed activity between shocks $(\boldsymbol{H})$, but does not affect activity during the pretest habituation phase $(I)$. N values are indicated in the figure. ${ }^{*} p<0.05 ;{ }^{* *} p<0.01 ;{ }^{* * *} p<0.001$.

Infralimbic and prelimbic lesions

Mice were assigned to IL lesion, sham IL lesion, PL lesion, or sham PL lesion groups, such that each cage had animals with both IL lesion and sham IL lesion, or PL lesion and sham PL lesion surgery types. Mice were anesthetized using isoflurane and underwent stereotactic surgery in which they received two bilateral injections of either ibotenic acid $(0.25$ $\mu \mathrm{l}$ of $5 \mathrm{mg} / \mathrm{ml}$ solution, $0.125 \mu \mathrm{l} / \mathrm{min}$ injection rate; Sigma-Aldrich) using a tapered glass micropipette with an internal diameter of $12 \mu \mathrm{m}$ (pulled from capillaries: 3-000-203-G/X, Drummond Scientific) if they were in the lesion groups, or with vehicle $(0.9 \% \mathrm{NaCl}, 0.25 \mu \mathrm{l}, 0.125$ $\mu \mathrm{l} / \mathrm{min}$ injection rate) if they were in the sham lesion groups. Injection coordinates were as follows: IL: 1.6 and $2.1 \mathrm{~mm}$ anterior to bregma, 2.8 $\mathrm{mm}$ ventral to bregma and $\pm 0.3 \mathrm{~mm}$ lateral to the midline; PL: 1.6 and $2.1 \mathrm{~mm}$ anterior to bregma, $2.0 \mathrm{~mm}$ ventral to bregma, and $\pm 0.3 \mathrm{~mm}$ lateral to the midline. After surgery, mice were returned to their cages and were monitored over the next week to ensure that they recovered without issue. Mice were given 2-4 weeks for recovery before the onset of behavioral testing.

\section{Histology}

At the end of the study, mice were transcardially perfused with PBS followed by $4 \%$ paraformaldehyde. Brains were excised and further fixed via incubation in $4 \%$ paraformaldehyde for $24 \mathrm{~h}$ after which they were cryoprotected by means of incubation in $30 \%$ sucrose for $3 \mathrm{~d}$. A freezing microtome was used to cut the entire anterior-posterior extent of the infralimbic or prelimbic region in $35 \mu \mathrm{m}$ sections. Sections were then stained with cresyl violet to determine the location and extent of the lesion by drawing out the regions of ibotenic acid-mediated neuronal loss that was visible on brain atlas figures. Post hoc analyses and histological verification were used to eliminate subjects that had mistargeted lesions from the study (two non-IL-lesioned mice were excluded).

\section{Statistical analysis}

Data were analyzed using Student's $t$ test, one-way ANOVA, or two-way ANOVA, with repeated measures where appropriate (StatView). Postnatal treatment and surgery type (sham vs lesion) were assessed as independent variables. Datasets containing male and female mice were analyzed for main effects and/or interactions of sex with the dependent variables under study. Since none were found, male and female data were combined. The criterion for significance was $p<0.05$. All data are presented as the mean \pm SEM.

\section{Results}

The sensitive time window in which 5-HT influences the development of adult affective behaviors is captured within the P2-P11 time period

The early postnatal, preweaning period in rodents from birth (P0) to P21, constitutes a developmental time window during which perturbations of 5-HTergic signaling alter adult anxiety and depression-like behaviors (Gross et al., 2002; Ansorge et al., 2004). However, this time period from birth until weaning in mice and the homologous human period starting with the third trimester of gestation and ending in early childhood, encompasses many developmental processes which hampers the identification of underlying mechanism and complicates translational interpretation. To overcome these limitations, we sought to re- 
A

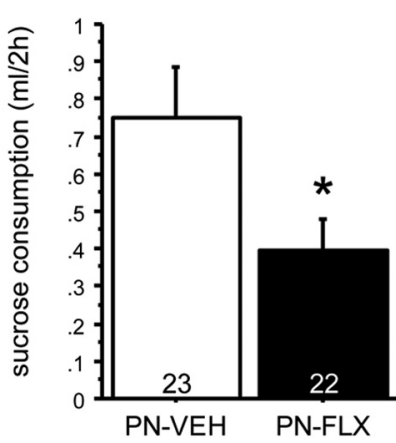

B

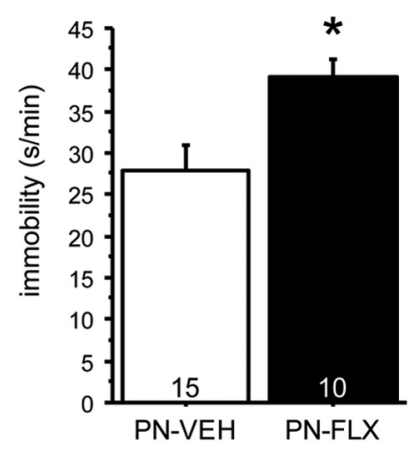

Figure 2. $P N-F L X$ from $P 2$ to $P 11$ increases depression-like behavior in the SPT and FST. $\boldsymbol{A}$, In the SPT, FLX treatment from $P 2$ to $P 11$ significantly reduced sucrose consumption. $B$, In the FST, FLX treatment from $\mathrm{P} 2$ to $\mathrm{P} 11$ results in significantly increased time spent immobile. $N$ values are indicated in the figure. ${ }^{*} p<0.05$.

fine the 5-HT-sensitive developmental epoch, hypothesizing that a narrower sensitive period exists within this 3 week time frame.

To test our hypothesis, we modulated 5-HT levels in early life by treating mice at multiple postnatal developmental periods with VEH or FLX, and examined anxiety- and depression-like behavior in adulthood. We investigated the following time windows: P2-P21, P2-P11, P12-P21, P22-P41 (Table 1). The P2$\mathrm{P} 21$ treatment epoch served as a positive control. The shorter P2-P11 and P12-P21 treatment groups served to test the hypothesis that a narrower sensitive period exists. A postweaningtreated group (P22-P41) was used to control for epoch specificity of behavioral effects. Behavioral testing was performed starting at P90.

We first tested mice in the OF conflict test used in rodents to characterize anxiety-like behavior. Mice were placed in a novel, brightly lit arena and allowed to explore freely. Classically, the amount of vertical activity (time spent rearing) and time spent in the more anxiogenic center of the $\mathrm{OF}$ arena are considered readouts for anxiety behavior based on the sensitivity of these parameters to subsedative doses of anxiolytic drugs. Additionally, ambulatory activity in the brightly lit, novel arena is an indicator of anxiety-like behavior as it reflects exploratory behavior in an anxiety-provoking context and is reduced in mouse models of affective disorders (Gross et al., 2002; Richardson-Jones et al., 2011). We did not detect an interaction between gender and time, gender and treatment, or gender and time and treatment for OF readouts (Table 3 ), and hence collapsed the data for gender. For total ambulatory time, we found both an overall effect of treatment $\left(F_{(1,155)}=9.485, p=0.0025\right.$; Fig. $\left.1 A\right)$ and a treatment $\times$ time interaction $\left(F_{(3,155)}=3.651, p=0.014\right)$. Post hoc analysis revealed that the main effect of treatment was carried by the P2-P21 and P2-P11 time windows (Fig. 1A). Specifically, mice treated with FLX from either P2-P21 (PN-FLX $($ P2-P21) mice) or P2-P11 (PN-FLX (P2-P11) mice) had significantly lower total ambulatory times, relative to their respective PN-VEH controls, demonstrating a suppression of exploratory behavior in a novel, anxiogenic environment. For time spent rearing, we again found a main effect of treatment $\left(F_{(1,155)}=11.106, p=0.0011\right)$. Post hoc analyses indicate that the effect of treatment is carried by an effect

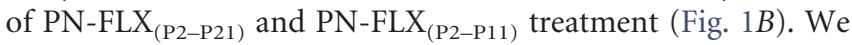
also detected a significant treatment $X$ time interaction in total time in the center $\left(F_{(3,155)}=2.94, p=0.035\right)$. Post hoc analyses revealed a significant decrease in time spent in the center specifically in the PN-FLX ${ }_{(\mathrm{P} 2-\mathrm{P} 11)}$ group (Fig. 1C). Thus, our findings in

the OF test are in line with the hypothesis that a smaller time window (P2-P11) exists during which PN-FLX treatment results in behaviors that are characteristic of enhanced anxiety.

To further assess the effect of PN-FLX treatment on adult emotional functioning, we performed the NSF test, in which food-deprived mice are presented with a familiar food pellet in a novel, brightly lit environment, and the latency to approach the food and begin a feeding bout is recorded. This behavioral paradigm is used to gauge the anxiety-/depression-like state of animals as both chronic antidepressant treatment and acute treatments with anxiolytic drugs decrease the latency to feed in this test. We found a significant main effect of both treatment and time $\left(F_{(1,162)}=11.783, p=0.0008\right.$ and $F_{(3,162)}=5.469, p=$ 0.0013 , respectively), as well as a significant interaction effect $\left(F_{(3,162)}=2.842, p=0.0396\right.$; Fig. $\left.1 D\right)$. No significant interactions with gender were detected (Table 3). Post hoc analyses revealed that these effects are caused by the PN-FLX $(\mathrm{P2}-\mathrm{P} 21)$ and PNFLX $_{(2-11)}$ treatment groups, both of which display significantly longer latencies to feed relative to controls (Fig. 1D). PN-FLX treatment from either P12-P21 or P22-P41, however, does not result in altered feeding latencies (Fig. 1D). The percentages of weight loss and home-cage food consumption after $24 \mathrm{~h}$ of food deprivation were comparable across groups (no significant main effects of treatment or time, treatment $\times$ time interaction, or respective interactions with gender; Fig. $1 E, F)$, indicating that the observed differences in PN-FLX $(2-21)$ and PN-FLX $(2-11)$ mice are not due to factors related to the degree of food deprivation or hunger.

We next examined the effects of PN-FLX treatment in the SESC paradigm, which assesses behavioral responses to stress. Latency to escape the shock is the primary dependent measure altered in rodent models of depression and anxiety disorders, and is sensitive to learned helplessness training as well as chronic antidepressant treatment. In this paradigm, we identified a significant main effect of treatment $\left(F_{(1,161)}=10.600, p=0.0014\right)$ and a treatment $\times$ time interaction effect $\left(F_{(3,161)}=7.299, p=\right.$ $0.0001)$ in escape latency. No significant interactions with gender were detected (Table 3). Post hoc analyses revealed that effects were carried by the significantly higher escape latencies in the PN-FLX ${ }_{(2-21)}$ and PN-FLX $(2-11)$ mice groups (Fig. $\left.1 G\right)$. Similarly, we found an effect of treatment on intratrial activity $\left(F_{(1,161)}=\right.$ 5.775, $p=0.174$ ) without gender interactions (Table 3 ). The treatment effect is due primarily to the significant decrease in intratrial movement solely in the PN-FLX $(2-21)$ and PN-FLX $(2-11)$ groups $($ Fig. $1 H)$. The longer latencies and suppression of movements in response to shock displayed by PN-FLX ${ }_{(2-21)}$ and PNFLX $_{(2-11)}$ mice were not due to an overall decrease in activity as no effects of treatment, time, or interaction were detected during the habituation period in the dark chamber (Fig. 1I). These findings demonstrate a diminished behavioral response to acute stress, which is indicative of an enhanced anxiety-/depressionlike state, selectively in the P2-P21 and P2-P11 treatment groups, as PN-FLX treatment during either P12-P21 or P22-P41 did not impact escape latencies, intratrial activity, or activity during the habituation period (Fig. $1 G-I$ ).

To investigate whether PN-VEH treatments affected behaviors in the OF, NSF, and SESC tests, we compared their performance to that of naive mice, which were bred and tested at the same time and raised under identical conditions, with the exception of postnatal injections and handling. We found no effect of treatment in the OF (ambulatory time: $F_{(4,99)}=1.282, p=$ 0.2824 ; time rearing: $F_{(4,99)}=0.9, p=0.4672$; center timer: $F_{(4,99)}$ $=1.765, p=0.142$ ), NSF (latency to feed: $F_{(4,103)}=0.571, p=$ 
A

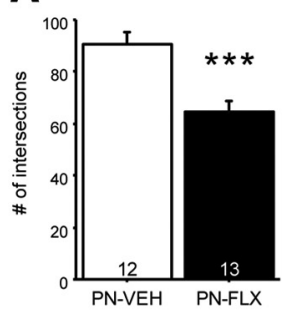

B

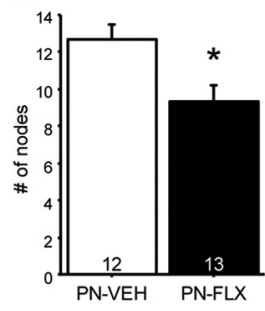

E

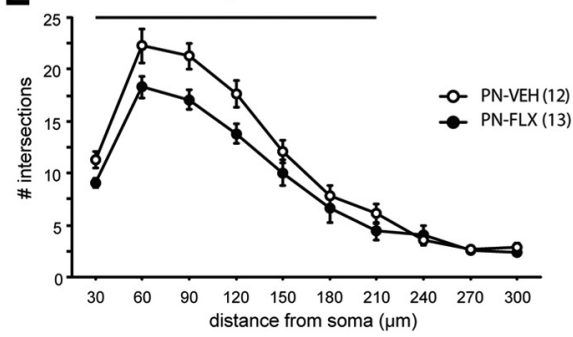

C

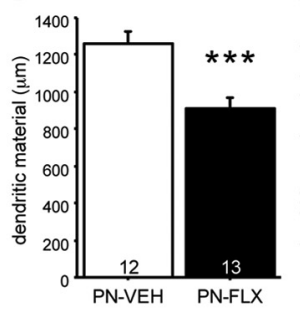

$F$

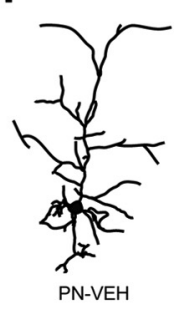

Figure 3. PN-FLX treatment alters dendritic morphology of IL pyramidal neurons. $\boldsymbol{A}-\boldsymbol{D}$, IL neurons from PN-FLX mice have significantly less complex apical dendritic trees, relative to controls, as evidenced by a decrease in the number of intersections $(\boldsymbol{A})$, number of nodes $(\boldsymbol{B})$, and dendritic material $(\boldsymbol{C})$, with no overall decrease in average apical arbor length $(\boldsymbol{D})$. $\boldsymbol{E}$, Decreased complexity was most pronounced in the proximal to medial region of the soma. $\boldsymbol{F}$, A schematic of altered dendritic morphology. $N=3$ mice/group; $N$ values for cells per condition are indicated in the figure. ${ }^{*} p<0.05$; ${ }^{* *} p<0.01$.

Table 4. Normal dendritic morphology in IL basilar arbors and PL apical and basilar arbors of PN-FLX mice

\begin{tabular}{lllll}
\hline & Intersections & \multicolumn{1}{l}{ Nodes } & Material & Length \\
\hline IL basilar & & & & \\
$\quad$ PN-VEH (19) & $75.3 \pm 6.4$ & $9.7 \pm 1.0$ & $1023.4 \pm 88.0$ & $217.7 \pm 12.9$ \\
$\quad$ PN-FLX (18) & $86.2 \pm 6.2$ & $11.1 \pm 0.8$ & $1146.5 \pm 81.1$ & $202.7 \pm 13.5$ \\
PL basilar & & & & \\
$\quad$ PN-VEH (12) & $97.1 \pm 9.3$ & $13.0 \pm 1.2$ & $1451.2 \pm 142.3$ & $136.4 \pm 7.5$ \\
$\quad$ PN-FLX (13) & $98.7 \pm 11.9$ & $14.0 \pm 1.2$ & $1371.7 \pm 144.7$ & $160.8 \pm 12.9$ \\
PL apical & & & & \\
$\quad$ PN-VEH (12) & $89.5 \pm 9.6$ & $15.3 \pm 2.2$ & $1263.3 \pm 133.3$ & $220.0 \pm 13.7$ \\
PN-FLX (14) & $91.4 \pm 12.2$ & $12.2 \pm 2.2$ & $1244.1 \pm 168.8$ & $223.6 \pm 17.7$ \\
\hline
\end{tabular}

Data are mean \pm SEM. PN-FLX treatment does not affect dendritic morphology of the IL basilar arbors, apical PL arbors or basilar PL arbors, as measured by number of intersections, nodes, total dendritic material, and dendritic tree length. $N$ values are indicated in parantheses.

0.6845; weight loss: $F_{(4,103)}=1.841, p=0.1267$; home-cage food consumption: $F_{(4,103)}=1.628, p=0.1728$ ), or SESC test (escape latency: $F_{(4,102)}=1.619, p=0.1752$; intratrial activity: $F_{(4,103)}=$ $2.298, p=0.064$; pretrial activity: $\left.F_{(4,103)}=1.372, p=0.2489\right)$.

After narrowing down the postnatal sensitive time period to P2-P11, we next examined the effect of PN-FLX exposure on depression-like behavior in a test that builds on the hedonic value of diluted sucrose, the sucrose preference test (SPT). We performed the SPT in an independent cohort of mice maintained at free-feeding body weights with access to water and chow ad libitum. Under such conditions, data are not affected by hunger, and water consumption is very low. We found a treatment effect on sucrose consumption with PN-FLX-treated mice consuming $\sim 50 \%$ when compared with PN-VEH controls $\left(t_{(1,43)}=4.948\right.$, $p=0.0314$; Fig. 2A). We found no effect of treatment on water consumption or body weights $\left(t_{(1,43)}=0.014, p=0.9058\right.$ and $t_{(1,43)}=1.562, p=0.2182$, respectively). Hence, we interpret these data to demonstrate that PN-FLX treatment reduces the hedonic drive to drink diluted sucrose, producing a depressionlike phenotype. No interactions between treatment and gender were detected (Table 3). A subset of mice underwent additional testing in a behavioral task with predictive validity for antidepres-
D
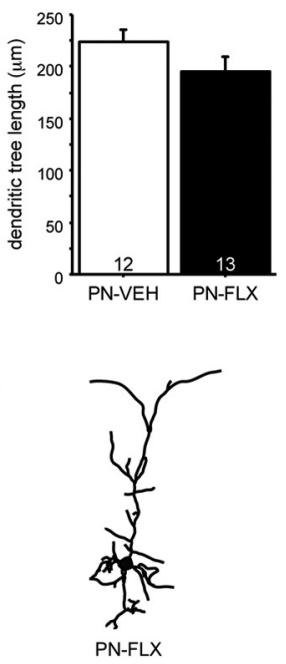

sant medication, the FST. We found an effect of treatment on floating time $\left(t_{(1,23)}\right.$ $=7.741, p=0.0106)$, with PN-FLXtreated mice floating more when compared with $\mathrm{PN}-\mathrm{VEH}$-treated control mice (Fig. 2B). No interaction between treatment and gender was detected (Table 3 ).

In summary, PN-FLX treatment from P2-P21 or P2-P11, but not P12-P21 or P21-P42, increases anxiety- and depression-like behavior in mice. Thus, the period in which the circuits underlying adult anxiety and depression behaviors are 5-HT-sensitive is contained within the narrower $\mathrm{P} 2-\mathrm{P} 11$ period. To test this conclusion using higher statistical vigor, we performed a post hoc analysis on all detected effects for $\mathrm{PN}-\mathrm{VEH}_{(\mathrm{P} 2-\mathrm{P} 11)}$ versus PN-FLX ${ }_{(\mathrm{P} 2-\mathrm{P} 11)}$, based on litters (i.e., litter averages) instead of individual mice. The effects in the OF, NSF, SESC, and FST reach significance (OF ambulatory time: $t_{(1,7)}=37.574, p=0.0005$; OF time rearing: $t_{(1,7)}=26.199, p=0.0014$; OF center time: $t_{(1,7)}=11.572, p=0.0114$; NSF latency to feed: $t_{(1,7)}=7.735, p=0.0273$; SESC escape latency: $t_{(1,7)}=28.656, p=0.0011$; SESC intratrial activity: $t_{(1,7)}=8.515, p=0.0224$; FST: $\left.t_{(1,8)}=8.026, p=0.022\right)$. The treatment effect in the SPT reached trend level $\left(t_{(1,8)}=4.54\right.$, $p=0.0657)$.

PN-FLX treatment reduces apical dendritic arbor complexity of infralimbic pyramidal neurons

Next, we sought to address the mechanism by which PN-FLX alters the brain in a permanent manner such that it impacts adult anxietyand depression-related behaviors. Based on the neurotrophic properties of 5-HT, and its influence on neuronal morphology, we hypothesized that developmental 5-HTT blockade would cause cytoarchitectural changes in neurons from brain regions that are implicated in anxiety and depression behaviors. Because the human 5-HTTLPR impacts $\mathrm{mPFC}$ anatomy and functional connectivity (Heinz et al., 2005; Pezawas et al., 2005), and, because lifelong 5-HTT ablation alters mPFC neuronal morphology (Wellman et al., 2007), we focused our analysis on the dendritic morphology of pyramidal neurons in the IL and PL subregions of the mPFC.

Dendritic morphology of Golgi-stained pyramidal neurons in the IL and PL regions from adult (>P90) PN-FLX and PN-VEH mice were examined by computer-assisted manual tracing of neurons followed by Sholl analysis. In the IL region, PN-FLX treatment reduces the number of intersections (Fig. $3 A ; F_{(1,23)}=$ 17.384, $p=0.0004$ ) and nodes (Fig. $3 B ; F_{(1,23)}=7.659, p=$ 0.011 ), and the total amount of dendritic material (Fig. $3 C ; F_{(1,23)}$ $=15.848, p=0.0006)$ of the apical dendritic arbor, relative to PN-VEH controls. These changes occur in the absence of any overall shrinkage of the apical tree, as no differences in tree length were detected (Fig. $3 D ; F_{(1,23)}=2.092, p=0.1616$ ). The effect of reduced complexity was observed over the entire proximal and medial aspects of the arbor, up to $120 \mu \mathrm{m}$ from the soma [Fig. 3E; (repeated-measures ANOVA) effect of treatment: $F_{(1,23)}=$ 13.663; $p=0.0012$; effect of distance: $F_{(3,69)}=58.982 ; p<$ 0.0001 ; treatment $\times$ distance interaction: $F_{(3,69)}=0.863 ; p=$ 0.4648]. The effect of PN-FLX treatment on arbor complexity 

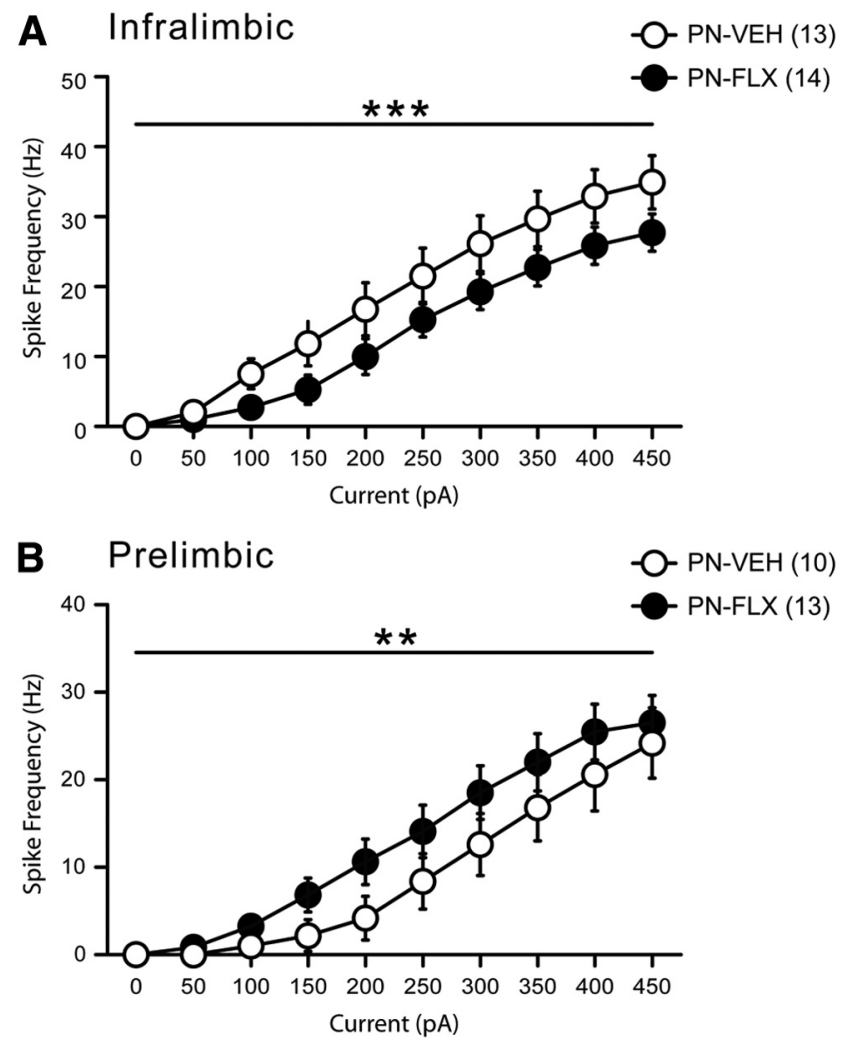

Figure 4. PN-FLX treatment results in concurrent and opposite changes in IL and PL neuronal excitability. Input- output curves displaying frequency (in $\mathrm{Hz}$ ) of spikes (action potentials) generated in response to increasing current injections (increased by $50 \mathrm{pA}$ per step), from resting membrane potential. $A$, IL pyramidal neurons from PN-FLX mice display a significantly lower frequency of spikes in response current steps relative to PN-VEH controls. $\boldsymbol{B}$, Conversely, prelimbic neurons from PN-FLX mice display significantly increased frequency of spikes in response to current injections. $N=3-6$ mice/treatment; $N$ values for cells per condition are indicated in the figure. ${ }^{* *} p<0.01 ;{ }^{* * *} p<0.001$.

was specific to the IL apical arbor, as no changes were detected in either the IL basilar dendrites, or in the apical or basilar PL arbors (Table 4).

Together, these data demonstrate that transient developmental 5-HTT blockade has a long-lasting and subregion-specific impact on neuronal morphology within the mPFC, reducing the apical dendritic complexity of IL pyramidal neurons.

\section{PN-FLX treatment concurrently decreases infralimbic and increases prelimbic neuronal excitability}

Neuronal activity in the $\mathrm{mPFC}$ has been associated with fear- and anxiety-related behaviors (Burgos-Robles et al., 2009; Covington et al., 2010). To determine whether the cytoarchitectural alterations in the mPFC were also accompanied by changes in the intrinsic activity of mPFC pyramidal neurons, we performed whole-cell patch-clamp recordings in acute brain slices from adult PN-FLX and PN-VEH mice.

First, we examined the intrinsic excitability of IL and PL neurons by measuring the spike frequencies in response to current injections delivered to neurons initially at resting membrane potential (Fig. 4). This measure of intrinsic excitability reflects the probability of a neuron to fire in response to incoming stimuli and, ultimately, may serve as a proxy for neuronal output capacity. In IL neurons, two-way ANOVA revealed a significant main effect of treatment group with PN-FLX mice displaying significantly fewer spikes to current injections (Fig. $4 A ; F_{(1,250)}=19.08$; $p<0.0001)$. Conversely, neurons from the PL region of PN-FLX mice responded to large current injections with significantly more spikes, relative to controls (Fig. $4 B ; F_{(1,210)}=6.12, p=$ 0.01 ). These diminished IL and enhanced PL responses to current injections were also observed when neurons were all held at the same initial membrane potential of $-75 \mathrm{mV}$ (data not shown).

These changes in IL and PL membrane excitability occurred in the absence of any major alterations in intrinsic neuronal properties such as resting membrane potential or input resistance (Table 5). PN-FLX PL neurons, however, display significantly reduced rheobase values $\left(F_{(9,17)}=42.4, p=0.04\right)$, relative to controls, which is congruent with their increased excitability. No treatment effect was detected for the frequency or amplitude of spontaneous EPSCs (sEPSCs) in either the IL or PL (Fig. 5A,B).

Inclusively, we found that transient developmental FLX treatment has opposing effects on electrophysiological properties of adult pyramidal neurons in an $\mathrm{mPFC}$ subregion-specific manner, decreasing excitability in the IL region and increasing it in the PL region. The frequency and amplitude of sEPSCs in these regions are not different, suggesting preserved glutamatergic inputs. Therefore, in response to typical endogenous excitation, the altered intrinsic properties of IL and PL neurons arising from a history of early FLX treatment would be expected to disrupt the balance of mPFC output.

\section{PN-FLX mice display deficits in fear extinction learning and recall}

Next, we sought to determine whether the cytoarchitectural and electrophysiological changes in the mPFC region of PN-FLX mice have functional consequences using $\mathrm{mPFC}$-sensitive behavioral paradigms. The effects of IL and PL output on fear learning and extinction behaviors have been thoroughly investigated, and changes in function of both regions can be probed and verified using specific behavioral tests. For instance, loss-of-function modifications of the IL result in diminished ability to learn and recall extinguished fear memories, while hypofunction of the PL is associated with dampened fear responses and an enhancement in both extinction learning and recall (Sierra-Mercado et al., 2006, 2011; Vidal-Gonzalez et al., 2006; Santini et al., 2008; Farrell et al., 2010). Conversely, increased IL output results in extinction learning and subsequent recall of the extinction memory, while hyperfunction of the PL results in dampened extinction learning and diminished extinction recall (Vidal-Gonzalez et al., 2006). Based on the morphological and physiological changes observed in the mPFC of PN-FLX mice, we hypothesized that PN-FLX treatment would impair cued fear extinction.

PN-VEH and PN-FLX mice underwent classic pavlovian cued fear conditioning. During the conditioning phase, mice were placed in a chamber (context A) and were presented with five tones [conditioned stimulus (CS)], each of which coterminated with a shock [unconditioned stimulus (US)] delivered through the grid floor of the chamber. Freezing responses were measured as the primary readout of fear in this paradigm. During fear conditioning, we detected no effect of treatment on preshock freezing, freezing immediately after tone-shock presentations, or post-training freezing (Fig. 6A). On the following day, PN-FLX mice underwent cued extinction training in a different chamber (context B). We found that both postnatal treatment groups exhibited comparably low baseline (pretone) freezing levels in the novel extinction learning context (Fig. 6B). With the onset of the first set of tones, a pronounced increase in freezing levels was observed in both PN-FLX and PN-VEH mice, signifying that both groups successfully acquired the CS-US association from 
Table 5. Intrinsic properties of pyramidal neurons in the IL and PL regions of adult PN-FLX and PN-VEH mice

\begin{tabular}{|c|c|c|c|c|c|}
\hline & $V_{m}(m V)$ & Spike amplitude (mV) & $\mathrm{R}_{\text {in }}(M \Omega)$ & $C_{m}(p F)$ & Rheobase (pA) \\
\hline \multicolumn{6}{|l|}{ IL layer II/III } \\
\hline Saline $(n=13)$ & $-85.5 \pm 2.8$ & $87.3 \pm 1.5$ & $165.0 \pm 25.9$ & $86.5 \pm 5.0$ & $134 \pm 26$ \\
\hline Fluoxetine $(n=19)$ & $-83.6 \pm 1.8$ & $84.9 \pm 1.2$ & $130.9 \pm 13.2$ & $91.6 \pm 9.0$ & $150 \pm 16(n=17)$ \\
\hline$p$ value & 0.6 & 0.2 & 0.2 & 0.7 & 0.6 \\
\hline \multicolumn{6}{|l|}{ PL layer II/III } \\
\hline Saline $(n=10)$ & $-86.6 \pm 2.4$ & $88.5 \pm 1.1$ & $77.9 \pm 15.4$ & $99.8 \pm 7.5$ & $255 \pm 31$ \\
\hline Fluoxetine $(n=20)$ & $-88.9 \pm 1.6$ & $83.7 \pm 1.4$ & $115.7 \pm 13.7$ & $87.1 \pm 4.9$ & $173 \pm 21(n=17)$ \\
\hline$p$ value & 0.4 & $0.04^{*}$ & 0.1 & 0.1 & $0.03^{*}$ \\
\hline
\end{tabular}

Data are mean \pm SEM. Vm, Resting membrane potential; spike amplitude in $\mathrm{mV} ; \mathrm{R}_{\mathrm{in}}$, input resistance; $C_{\mathrm{m}}$, membrane capacitance. $N$ values are indicated in the table. ${ }^{*} p<0.05$.

A

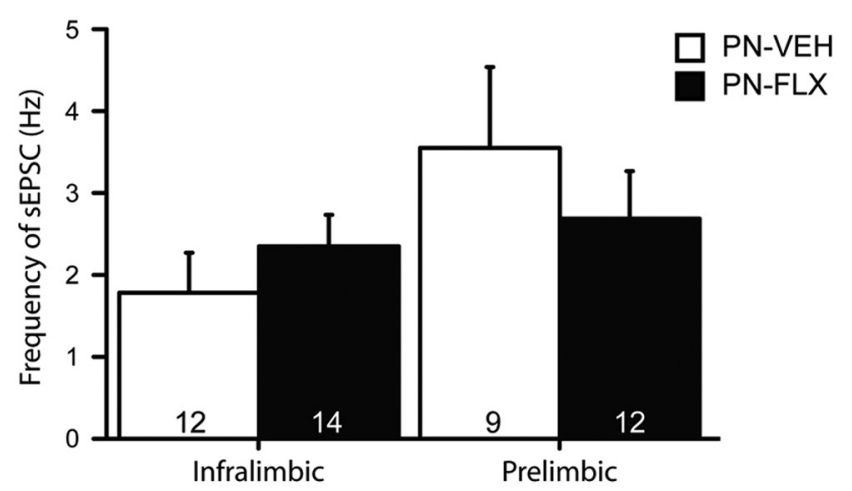

B

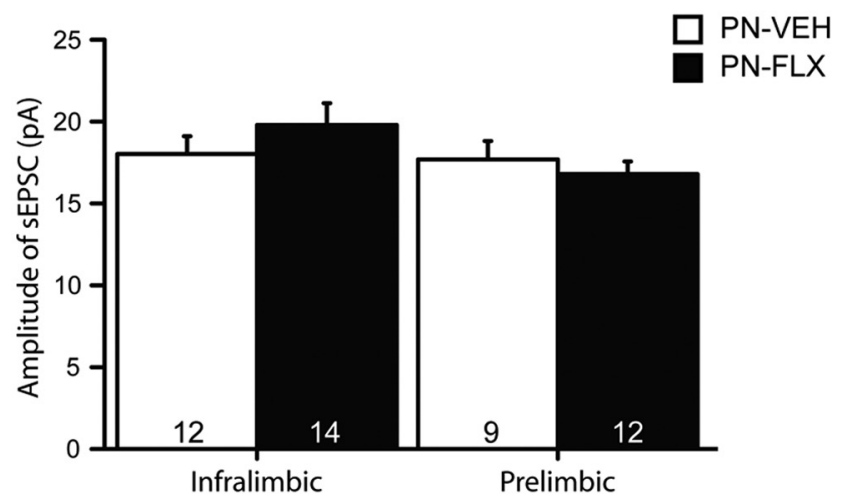

Figure 5. Normal sEPSCs in IL and PL pyramidal neurons of PN-FLX mice. $\boldsymbol{A}, \boldsymbol{B}, \mathrm{PN}-\mathrm{FLX}$ treatment does not alter the frequency $(\boldsymbol{A})$ or amplitude $(\boldsymbol{B})$ of sEPSCs in IL (left) or PL (right) pyramidal neurons. $N=3-6$ mice/treatment; $N$ values for cells per condition are indicated in the figure.

the fear conditioning session of the previous day (Fig. $6 B$, tones $1-5)$. During the extinction training session (D1), we detected a treatment $\times$ time effect $\left(F_{(5,235)}=3.204, p=0.0081\right)$. Gender did not interact with treatment $X$ time (Table 3$)$. Post hoc analysis revealed that $\mathrm{PN}-\mathrm{VEH}$ controls exhibited robust extinction learning, as indicated by a progressive decrease in freezing over time with exposure to each subsequent set of tones (main effect of time for PN-VEH: $F_{(5,115)}=11.932, p<0.0001$; Fig. $\left.6 B\right)$. PNFLX mice also displayed extinction learning (main effect of time for PN-FLX: $\left.F_{(5,120)}=3.104, p=0.0114\right)$, but with a blunted decrease in freezing levels over the extinction training session (Fig. 6B). Post-tone freezing levels of PN-FLX mice were also significantly higher than those of controls $\left(F_{(1,47)}=14.211 ; p=\right.$ 0.0005 ), and gender did not interact with treatment (Table 3). A statistical analysis based on litter averages produces comparable results (treatment $\times$ time effect: $F_{(5,55)}=2.303, p=0.057$; main effect of time for PN-VEH: $F_{(5,30)}=14.313, p<0.0001$; main effect of time for PN-FLX: $F_{(5,25)}=3.14, p=0.0246$; post-tone freezing levels: $\left.F_{(1,11)}=22.655, p=0.0006\right)$. To investigate extinction learning and recall over several days, freezing levels were normalized to the individual freezing values at the beginning of the first extinction session. Extinction learning and recall were affected by treatment, as indicated by the treatment $\times$ time interaction $\left(F_{(4,164)}=3.228, p=0.0140\right)$. Gender did not interact with treatment $\times$ time interaction (Table 3 ). As for the unnormalized data, we find that PN-FLX mice display diminished extinction learning on D1 (time $\times$ treatment interaction: $F_{(1,41)}$ $=11.038 ; p=0.0019$; Fig. $6 C$ ). On D2, neither PN-VEH nor PN-FLX mice displayed extinction recall (D2 start vs D1 start: not statistically significantly different for either PN-VEH or PNFLX). On D2, both PN-VEH and PN-FLX mice displayed comparable levels of extinction learning (no time $\times$ treatment interaction; main effect of time: $\left.F_{(1,41)}=29.490 ; p<0.0001\right)$. However, on D3, despite learning to extinguish the CS-US memory to the same extent as PN-VEH mice on D2, PN-FLX mice do not display extinction recall, unlike their $\mathrm{PN}-\mathrm{VEH}$ controls that do (Fig. 6C). A statistical analysis based on litter averages produces comparable results (treatment $\times$ time effect: $F_{(4,44)}=$ 2.018, $p=0.1084$; D1 time $\times$ treatment effect: $F_{(1,11)}=3.872$, $p=0.0748$; D2 main effect of time: $F_{(1,11)}=24.083, p=0.0005$; post hoc comparison of beginning D2 vs beginning D3 in PNVEH mice: $p=0.0343$; post hoc comparison of beginning D2 vs beginning D3 in PN-FLX mice: $p=0.9618$ ).

Overall, our findings demonstrate that mice experiencing FLX exposure in postnatal development display deficits in both the learning and memory components of fear extinction, and suggest that there exists a decrease in the IL/PL output ratio in PN-FLX mice.

IL lesions but not PL lesions result in a partial phenocopy of the PN-FLX mouse behavioral phenotype

Next, we sought to address the question of whether altered mPFC activity could cause the increased anxiety- and depression-like behavior observed in PN-FLX mice. Specifically, we hypothesized that mimicking decreased IL activity would result in a phenocopy of the PN-FLX behavioral profile in the OF, the NSF, and the SESC test. Conversely, we hypothesized that reducing PL activity would result in an anxiolytic/antidepressant phenotype.

To decrease IL or PL activity, we selectively lesioned the IL or $\mathrm{PL}$ region of mice. Specifically, adult mice underwent stereotactic surgery in which they received two bilateral injections of the neurotoxin ibotenic acid resulting in cell death and gliosis of the IL or PL cortex, while control mice were stereotactically sham lesioned with saline solution. After a minimum 2 week recovery period, mice underwent behavioral testing, after which mice were killed and lesion locations were histologically determined (Figs. 7A, B, 
A Fear conditioning

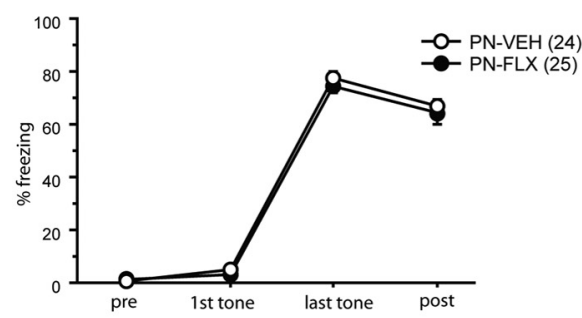

B Extinction learning

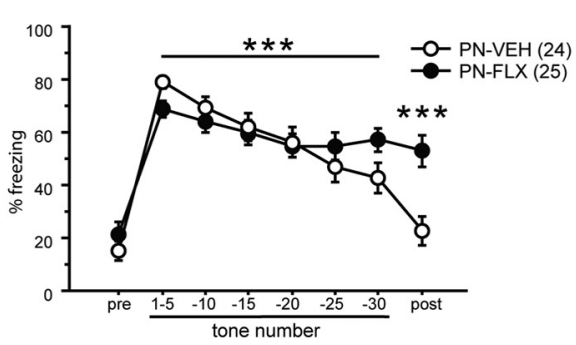

C Extinction learning and recall

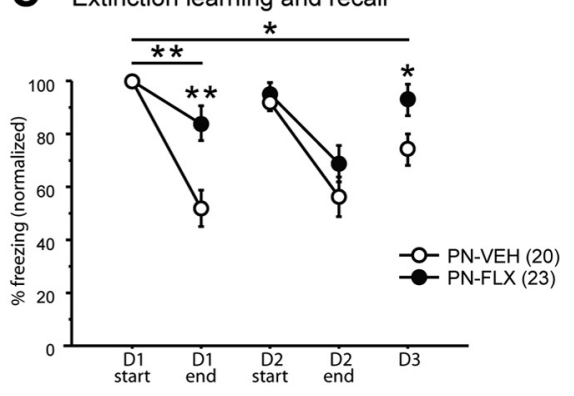

Figure 6. PN-FLX treatment results in fear extinction learning and recall deficits. A, PN-FLX mice exhibit comparable levels of freezing at baseline (pre), in response to the first and last tones of the training session, and in the post-training period (post), when compared with PN-VEH controls. $\boldsymbol{B}$, During the extinction learning session, no baseline differences in pretone freezing in a novel extinction training environment is observable (pre). $\boldsymbol{B}$, After the onset of the tones (without shocks), PN-VEH mice exhibit a progressive decrease in freezing to tone over the extinction session, while PN-FLX mice display significantly blunted decreases in freezing over the session (horizontal line indicates significant treatment $X$ time interaction). PN-FLX mice also exhibit significantly higher post-training freezing levels, relative to controls ( $\boldsymbol{B}$, post). $\boldsymbol{C}$, To investigate freezing behavior over multiple days, freezing levels of PN-FLX and PN-VEH mice were normalized to their respective starting freezing levels at D1. As observed in the non-normalized data of $\boldsymbol{B}$, PN-FLX-treated mice displayed a deficit in extinction learning, when compared with PN-VEH controls on D1 (C, horizontal line indicates significant treatment $X$ time interaction, stars without horizontal line indicate treatment effect on D1 end). Between D1 and D2, neither PN-VEH nor PN-FLX mice displayed extinction recall (D1 start vs D2 start, not statistically significantly different for either PN-VEH or PN-FLX). On D2, PN-VEH and PN-FLX mice displayed extinction learning (main effect of effect of time, no time $X$ treatment interaction). Between D2 and D3, only PN-VEH displayed extinction recall, and PN-FLX mice froze significantly more than PN-VEH mice on D3. N values are indicated in the figure. ${ }^{*} p<$ $0.05 ; * * 0.01 ; * * * 0.001$.

$8 A, B)$. We did not detect an interaction between gender and treatment for OF, NSF, or SESC readouts (Table 3), and hence collapsed the data for gender.

In the OF test, no effect of IL lesioning on ambulatory time was observed (Fig. 7C). However, two-way ANOVA demonstrated a significant effect of surgery on both rearing time and time in center, with IL lesioned mice exhibiting significantly decreased time rearing and time in center, relative to controls (Fig. $7 D, E ; F_{(1,49)}=4.285, p=0.0437$ and $F_{(1,49)}=4.667, p=0.0357$, respectively), suggesting an enhancement of anxiety-like behavior in IL-lesioned animals relative to sham controls.

IL lesions also significantly increased feeding latencies in a novel, anxiogenic environment in the NSF test (Fig. $7 F ; F_{(1,48)}=$ $4.328, p=0.0429$ ), while home-cage food consumption and the percentage of weight loss after $24 \mathrm{~h}$ of food deprivation was unchanged (Fig. 7G,H). This finding also suggests that decreased IL output enhances anxiety-like behaviors.

In the SESC test, lesioning the IL was not sufficient to phenocopy the increased latency to escape phenotype characteristic of PN-FLX mice as no differences in escape latencies, the intratrial activity, or baseline ambulatory activity (during the habituation phase) between IL and sham-lesioned mice were detected (Fig. $7 I-K)$.

In contrast to the IL lesions, PL lesions did not affect behavior in the OF or NSF test (Fig. 8), but increased intratrial activity in the SESC test (Fig. 8J; $F_{(1,42)}=4.079, p=0.0498$ ).

Overall, our data demonstrate that lesioning the IL region in control mice is sufficient to phenocopy some, but not all, components of the anxiety- and depression-like behaviors characterized in PN-FLX mice.

\section{Discussion}

Our experiments demonstrate the existence of an early postnatal (P2-P11) FLX-sensitive period that affects emotional and cognitive behaviors in adulthood. We identify cytoarchitectural and electrophysiological correlates in the mPFC that indicate loss-offunction consequences for the IL region and gain-of-function consequences for the PL region. Excitotoxic IL lesions reproduce anxiety-related phenotypes, suggesting a causal chain of events where increased 5-HT signaling during P2-P11 reduces IL function in adulthood, which in turn leads to increased anxiety and fear extinction deficits.

\section{P2-P11 constitutes an FLX-sensitive period affecting adult emotional and cognitive behaviors}

We narrowed the time window during which FLX exposure impacts adult emotional behavior in mice from P2-P21 to P2-P11, and conversely found that FLX treatment during P12-P21 or P22-P41 does not affect these same behaviors. Strikingly, this time window maps onto a peak of twofold magnitude in cortical 5-HT and 5-hydroxyindoleacetic acid levels (Hohmann et al., 1988), and lies within the maturation period of both 5-HTergic afferents and cortical circuits (Lidov and Molliver, 1982a,b; Kiyasova and Gaspar, 2011; Vitalis et al., 2013). Our findings parallel the lack of long-lasting consequences on fear-, anxiety-, or stress-related behaviors following periadolescent FLX exposure in mice (Norcross et al., 2008). Rat studies, however, demonstrate increases in anxiety-like behavior following P25-P46, P35-P49, or P67-P88 5-HTT blockade when tested 1-21 d after treatment in the elevated plus maze (Karpova et al., 2009; Iñiguez et al., 2010). These findings suggest that 5-HT-sensitive periods have species-specific characteristics.

Interestingly, both mouse and rat studies reveal timingdependent bidirectional long-lasting effects of chronic 5-HTT blockade on FST behavior. Clomipramine exposure from P8 to P21 increases floating during FST of adult rats (Vogel et al., 1990); however, periadolescent (P35-P49), but not adult (P65P79), FLX exposure reduces floating $21 \mathrm{~d}$ after treatment secession (Iñiguez et al., 2010). In mice, we find increased floating after P2-P11 FLX exposure, while P4-P21 FLX exposure reduces long-lasting floating (Karpova et al., 2009). Thus, FST behavior might be differentially sensitive to the timing of 5-HTT blockade when compared with OF, NSF, and SESC behaviors. Yet, the convergence of behavioral malleability when interfering with 5-HT signaling during P2-P11 highlights the importance of this time window for circuit maturation and circuit plasticity. 
A

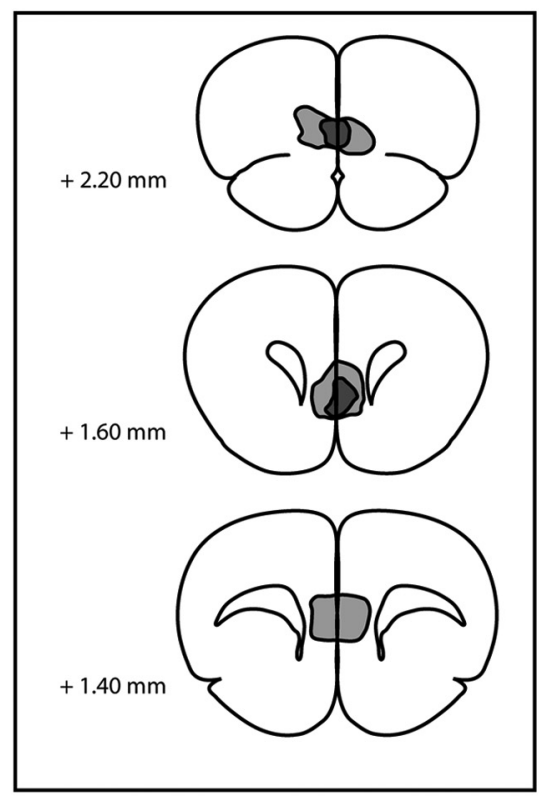

B

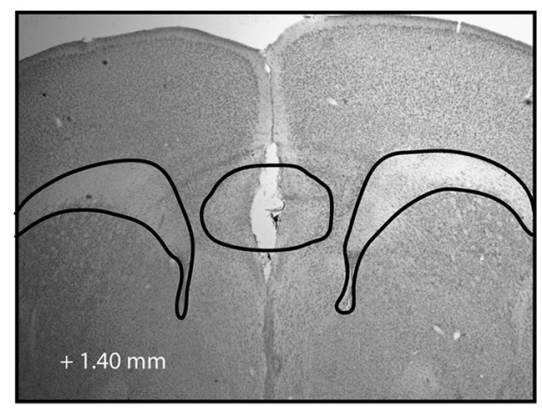

C

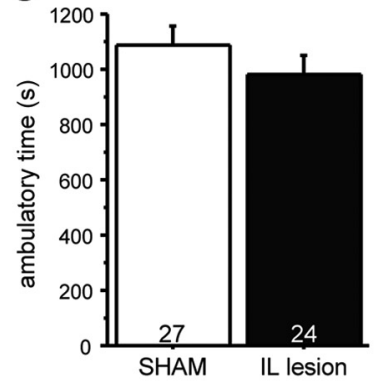

F

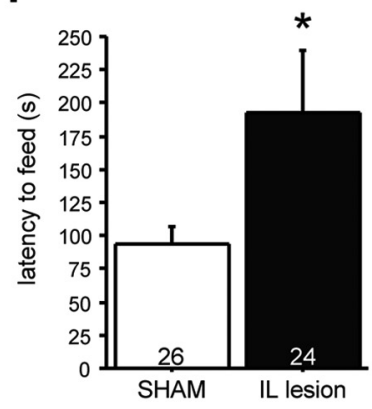

I

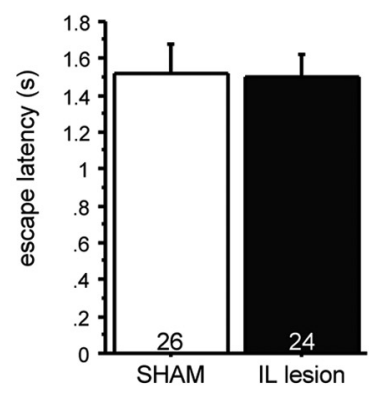

D

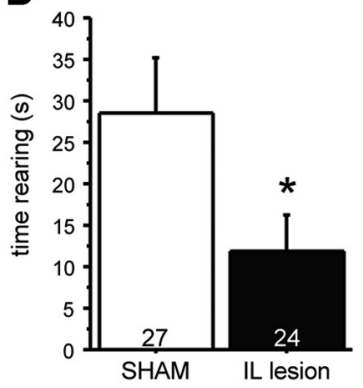

G

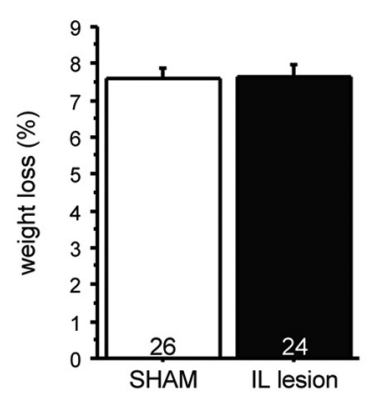

J

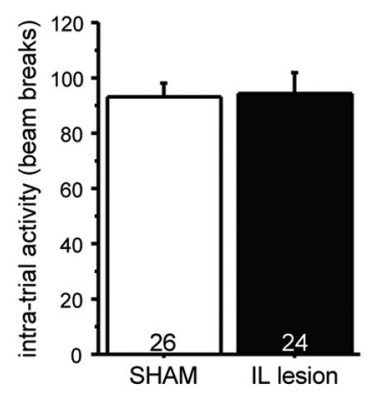

E

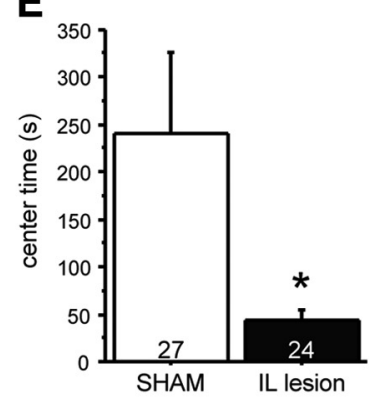

H

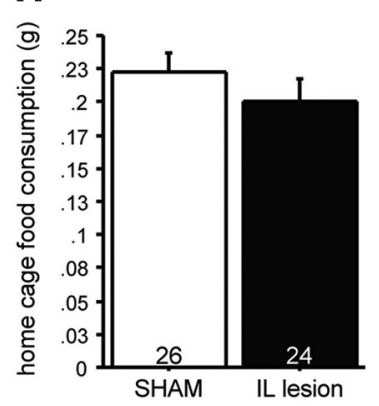

K

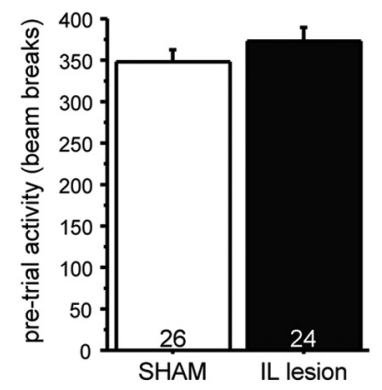

Figure 7. IL lesions in control mice phenocopy the effects of PN-FLX treatment on anxiety-like behavior. Mice received bilateral injections in the IL using ibotenic acid (IL lesion) or saline solution (SHAM). $\boldsymbol{A}, \boldsymbol{B}$, Lesion extent was assessed histologically after behavioral experiments were concluded, with light gray demarcating the additive area lesioned, and dark gray demarcating the largest common area lesioned. $\boldsymbol{C}-\boldsymbol{E}$, Although IL lesions do not alter ambulatory time in the $0 \mathrm{~F}$ test $(\boldsymbol{C})$, they significantly reduce the time spent rearing $(\boldsymbol{D})$ and the time spent in the more anxiogenic center region $(\boldsymbol{E})$ relative to SHAM lesioned controls. $\boldsymbol{F}-\boldsymbol{H}$, In the NSF test, IL lesioned mice take significantly longer to approach the food pellet relative to PN-VEH mice $(\boldsymbol{F})$, while the percentage of weight loss after $24 \mathrm{~h}$ of food deprivation $(\boldsymbol{G})$ and home-cage food consumption $(\boldsymbol{H})$ are comparable. $\boldsymbol{I}-\boldsymbol{K}$, IL lesions did not significantly affect latency to escape $(\boldsymbol{I})$, intratrial activity $(\boldsymbol{J})$, or baseline pretrial activity $(\boldsymbol{K})$ in the shock escape test. $N$ values are indicated in the figure. ${ }^{*} p<0.05$.

\section{Developmental FLX exposure affects the cytoarchitectural development of the mPFC}

We found reduced arborization of apical dendrites of IL pyramidal neurons in PN-FLX mice, indicating that the structural development of the mPFC is sensitive to P2-P11 selective serotonin reuptake inhibitor (SSRI) exposure. A similar 5-HT sensitivity has been reported for pyramidal neurons in the somatosensory cortex, where increased 5-HT signaling from embryonic day 8 (E8) to E18 decreases both apical and basilar dendritic arbor complexity (Chameau et al., 2009; Smit-Rigter et al., 2012). The mechanism by which this occurs is dependent on Cajal-Retzius cells, which release the glycoprotein reelin in a 5-HT3ARdependent fashion. Reelin in turn acts to inhibit the extent to which dendritic elaboration occurs (Chameau et al., 2009; SmitRigter et al., 2011). This mechanistic model is congruent with the dendritic phenotype of PN-FLX mice, because Cajal-Retzius cells are still present and active in the first 2 postnatal weeks (SmitRigter et al., 2012).

The cytoarchitectural sensitivity of the IL region is not limited to early-life FLX treatment. Both chronic mild stress and brief uncontrollable stress in adulthood cause a retraction in the apical trees of IL pyramidal neurons (Radley et al., 2005; Izquierdo et al., 2006; Liston et al., 2006; Farrell et al., 2010), suggesting that IL dendritic arbors are particularly plastic. Furthermore, stress can increase 5-HT levels in various brain regions, including the mPFC (Mokler et al., 2007; Alexander et al., 2009). Thus, the stress-induced and PN-FLX-generated hypotrophy of the IL may occur via similar mechanisms. Importantly, while adult stressinduced changes in $\mathrm{mPFC}$ morphology are reversible (Radley et al., 2005; Goldwater et al., 2009), early-life stress has sensitive period characteristics, producing long-term, stable alterations on mPFC dendritic arbors (Murmu et al., 2006; Mychasiuk et al., 2012).

Developmental FLX exposure has long-lasting impact on mPFC neurophysiology and fear extinction behavior

We found increased IL and decreased PL pyramidal neuron excitability in layer $2 / 3$ of PN-FLX mice. The lack of changes in input resistance and membrane capacitance in the same neurons suggests that the cytoarchitectural alterations caused by PN-FLX 
A

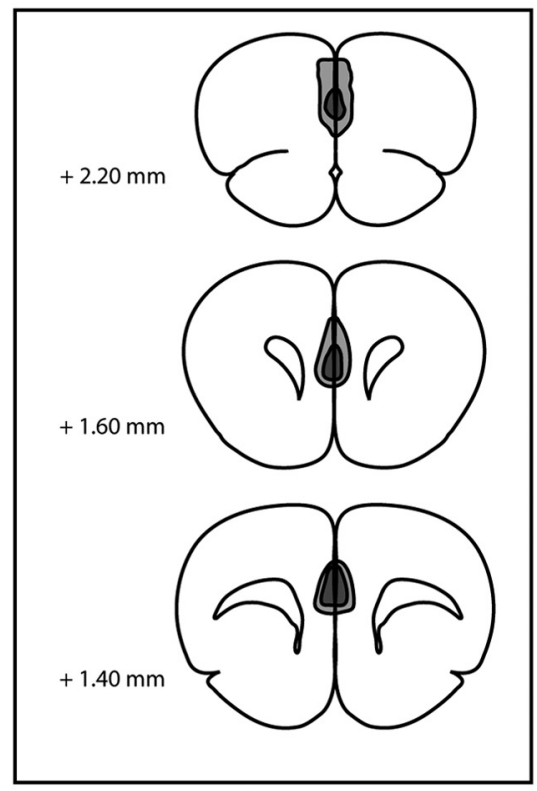

B

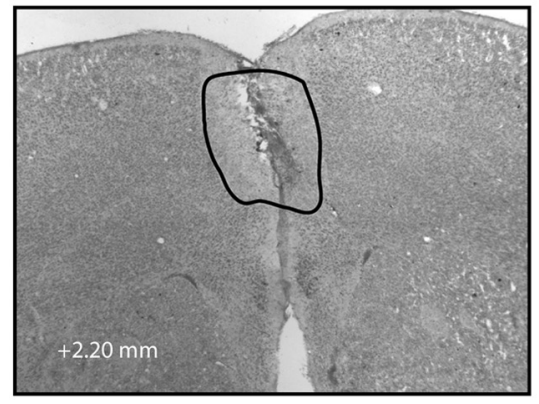

C

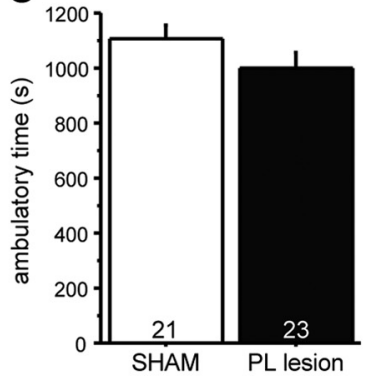

F

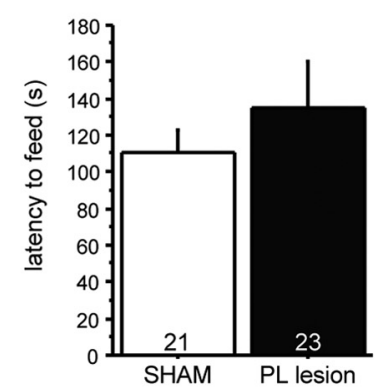

I

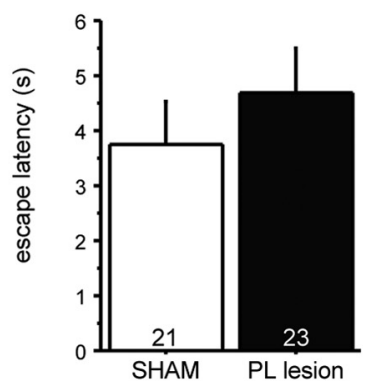

D

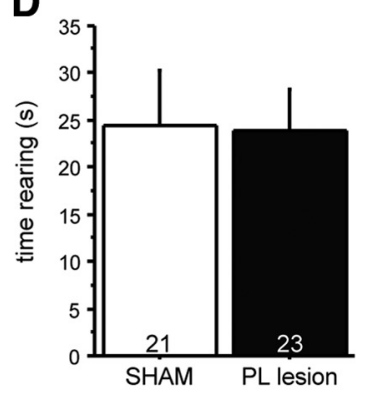

G

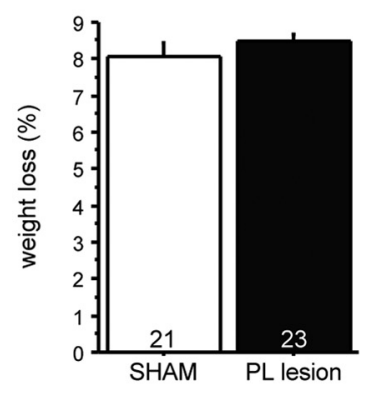

J

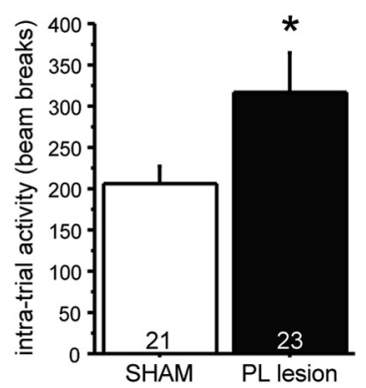

E

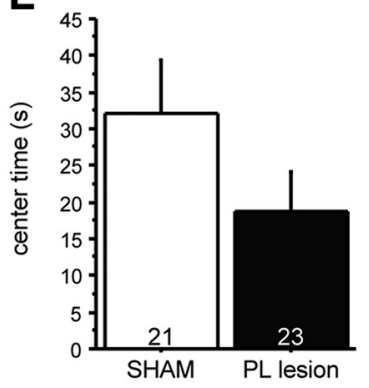

H
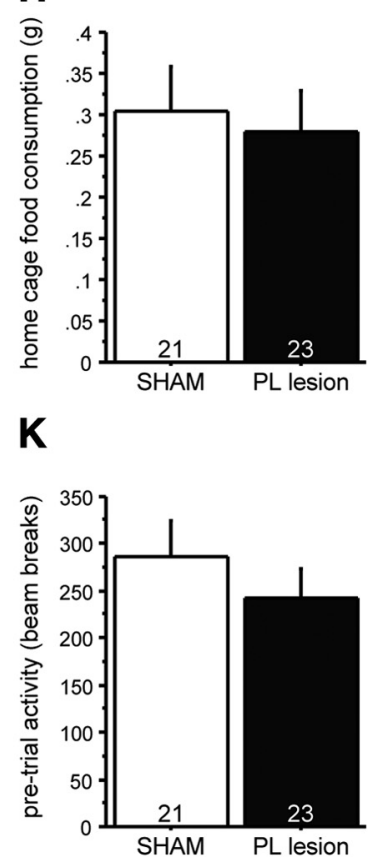

Figure 8. PL lesions in control mice do not affect anxiety-like behavior. Mice received bilateral injections in the PL using ibotenic acid (PL lesion) or saline solution (SHAM). $\boldsymbol{A}, \boldsymbol{B}$, Lesion extent was assessed histologically after behavioral experiments were concluded, with light gray demarcating the additive area lesioned, and dark gray demarcating the largest common area lesioned. $C-E$, In the $\mathrm{OF}$ test, PL lesions do not alter ambulatory time $(\boldsymbol{C})$, time spent rearing $(\boldsymbol{D})$, or time spent in the center region $(\boldsymbol{E})$ relative to SHAM lesioned controls. $\boldsymbol{F}$ - $\boldsymbol{H}$, In the NSF test, PL lesions do not affect the time to feed $(\boldsymbol{F})$, percentage of weight loss after $24 \mathrm{~h}$ of food deprivation $(\boldsymbol{G})$, or home-cage food consumption $(\boldsymbol{H}) . \boldsymbol{I}, \boldsymbol{K}$, PL lesions do not impact the latency to escape $(\boldsymbol{I})$ or baseline pretrial activity $(\boldsymbol{K})$ in the SESC test. $J$, PL lesions significantly increased the intratrial activity. $N$ values are indicated in the figure. ${ }^{*} p<0.05$.

treatment may be concomitant, but not causal, to the neurophysiological phenotype of PN-FLX mice. But diminished dendritic complexity coupled with reduced excitability in the IL might synergize to reduce functional activity.

IL and PL pyramidal neurons act antagonistically on amygdala activity, opposingly affecting the central nucleus of the amygdala (CeA), its main output (Milad and Quirk, 2002; Quirk et al., 2006; Quirk and Mueller, 2008). For example, local inhibition or lesions of the IL produce fear extinction deficits (Sierra-Mercado et al., 2006, 2011; Farrell et al., 2010; Santini and Porter, 2010); extinction recall is associated with increased burst firing in IL pyramidal neurons (Milad and Quirk, 2002; Rabinak et al., 2008; Santini et al., 2008; Santini and Porter, 2010); and enhanced PL excitability is associated with deficits in fear extinction learning and recall (Vidal-Gonzalez et al., 2006; Santini et al., 2008; Burgos-Robles et al., 2009; Sierra-Mercado et al., 2011). Guided by these findings, we probed fear extinction behavior and found reduced fear extinction learning and recall in PN-FLX mice, as predicted by the model. Interestingly, the retraction of the IL apical arbors that occurs with chronic stress is also associated with extinction deficits (Izquierdo et al., 2006). The human ho- molog to the murine IL arbor is thought to be the subgenual anterior cingulate cortex, which has been implicated in the biology of depression and anxiety (Mayberg, 2003, 2005; Covington et al., 2010; Price and Drevets, 2010). A similar correlation between changes in $\mathrm{mPFC}$ structure/function and behavior has been described in human " $s$ " allele carriers (Pezawas et al., 2005), who may be more vulnerable to developing post-traumatic stress disorder and anxiety-like behaviors (Caspi et al., 2003; Lee et al., 2005; Kilpatrick et al., 2007). Our data suggest that the diminished ability to quench traumatic memories, and associated anxiety, is due to dysfunctional mPFC output caused by exposure to increased 5-HTergic signaling during development.

\section{IL-dependent anxiety-related behaviors}

We report that excitotoxic IL lesions decrease anxiolytic-sensitive behavior in the novel OF and NSF tests, but do not alter OF ambulatory activity or behavior in the SESC test, producing a partial phenocopy of PN-FLX treatment. Reduced excitatory input from the IL to the GABAergic intercalated cell mass, which in turn disinhibits output activity of the CeA increases fear behaviors (Cassell and Wright, 1986; Paré and Smith, 1993; Mcdonald 
et al., 1996; Royer et al., 1999) and decreases fear extinction (Peters et al., 2009). Chronic disinhibition of CeA output through hypofunction of the IL might likewise underlie the sustained increase in anxiety-like behavior in the absence of any conditioned or innate threat observed here.

In contrast to IL lesions, PL lesions did not alter anxietyrelated behaviors. Such dissociation between IL and PL function parallels the role of $\mathrm{mPFC}$ in fear conditioning, where the PL function is selectively implicated in the acquisition and expression of conditioned fear behaviors (Baeg et al., 2001; Gilmartin and McEchron, 2005; Burgos-Robles et al., 2009), but not the expression of innate fear (Corcoran and Quirk, 2007). The PL lesion is furthermore involved in learned helplessness, where PL layer $2 / 3$ pyramidal neuron synaptic weakening is linked to stress resilience, while synaptic potentiation causes learned helplessness (Wang et al., 2014). While we do not find an impact of PL lesioning on escape latencies, we do find increased intratrial activity in the SESC test. This phenotype opposes the reduced intratrial activity seen after PN-FLX treatment, which also increases PL layer $2 / 3$ pyramidal neuron excitability. These data indicate that intratrial activity in the SESC paradigm might relate to the stress resilience/learned helplessness phenotype.

Together, our findings indicate that the observed alterations in mPFC function of PN-FLX mice cause their anxiety phenotype in the OF and NSF tests, and their stress responsivity phenotypes in the SESC test. However, the lack of an effect of mPFC lesions on novelty exploration and escape latencies suggests that other brain regions exist whose developmental trajectories are sensitive to 5-HT signaling during the PN period, and whose altered functions contribute to the emotional phenotype of PN-FLX mice. The dorsal raphe, the hippocampus, and the amygdala are candidate regions that might fulfill these criteria.

\section{Conclusion}

Our studies provide a developmental mechanism for the etiology and pathophysiology of increased affective and fear-related behaviors. This mechanism centers on increased 5-HT signaling during P2-P11 in mice, which approximately corresponds to the third trimester of human development. As a pathophysiological hallmark, which might be causally linked to behavior, we have identified IL hypotrophy and hypoexcitability as well as PL hyperexcitability. While our findings have closest relevance to the potential risk of gestational SSRI exposure, we relate our model to any factor, genetic or environmental, that alters 5-HT signaling during the sensitive developmental time window. If the net consequence is increased 5-HT signaling during the species homolog of murine P2-P11, our model predicts altered mPFC function and increased anxiety- and fear-related behavior in adulthood.

\section{References}

Adhikari A, Topiwala MA, Gordon JA (2011) Single units in the medial prefrontal cortex with anxiety-related firing patterns are preferentially influenced by ventral hippocampal activity. Neuron 71:898-910. CrossRef Medline

Alexander GM, Rogan SC, Abbas AI, Armbruster BN, Pei Y, Allen JA, Nonneman RJ, Hartmann J, Moy SS, Nicolelis MA, McNamara JO, Roth BL (2009) Remote control of neuronal activity in transgenic mice expressing evolved G protein-coupled receptors. Neuron 63:27-39. CrossRef Medline

Ansorge MS, Zhou M, Lira A, Hen R, Gingrich JA (2004) Early-life blockade of the 5-HT transporter alters emotional behavior in adult mice. Science 306:879-881. CrossRef Medline

Ansorge MS, Hen R, Gingrich JA (2007) Neurodevelopmental origins of depressive disorders. Curr Opin Pharmacol 7:8-17. CrossRef Medline

Ansorge MS, Morelli E, Gingrich JA (2008) Inhibition of serotonin but not norepinephrine transport during development produces delayed, persistent perturbations of emotional behaviors in mice. J Neurosci 28:199_ 207. CrossRef Medline

Atmaca M, Onalan E, Yildirim H, Yuce H, Koc M, Korkmaz S, Mermi O (2011) Serotonin transporter gene polymorphism implicates reduced orbito-frontal cortex in obsessive-compulsive disorder. J Anxiety Disord 25:680-685. CrossRef Medline

Baeg EH, Kim YB, Jang J, Kim HT, Mook-Jung I, Jung MW (2001) Fast spiking and regular spiking neural correlates of fear conditioning in the medial prefrontal cortex of the rat. Cereb Cortex 11:441-451. CrossRef Medline

Bale TL, Baram TZ, Brown AS, Goldstein JM, Insel TR, McCarthy MM, Nemeroff CB, Reyes TM, Simerly RB, Susser ES, Nestler EJ (2010) Early life programming and neurodevelopmental disorders. Biol Psychiatry 68: 314-319. CrossRef Medline

Benekareddy M, Goodfellow NM, Lambe EK, Vaidya VA (2010) Enhanced function of prefrontal serotonin 5-HT(2) receptors in a rat model of psychiatric vulnerability. J Neurosci 30:12138-12150. CrossRef Medline

Burgos-Robles A, Vidal-Gonzalez I, Quirk GJ (2009) Sustained conditioned responses in prelimbic prefrontal neurons are correlated with fear expression and extinction failure. J Neurosci 29:8474-8482. CrossRef Medline

Caldji C, Tannenbaum B, Sharma S, Francis D, Plotsky PM, Meaney MJ (1998) Maternal care during infancy regulates the development of neural systems mediating the expression of fearfulness in the rat. Proc Natl Acad Sci U S A 95:5335-5340. CrossRef Medline

Caspi A, Sugden K, Moffitt TE, Taylor A, Craig IW, Harrington H, McClay J, Mill J, Martin J, Braithwaite A, Poulton R (2003) Influence of life stress on depression: moderation by a polymorphism in the 5-HTT gene. Science 301:386-389. CrossRef Medline

Cassell MD, Wright DJ (1986) Topography of projections from the medial prefrontal cortex to the amygdala in the rat. Brain Res Bull 17:321-333. CrossRef Medline

Chameau P, Inta D, Vitalis T, Monyer H, Wadman WJ, van Hooft JA (2009) The N-terminal region of reelin regulates postnatal dendritic maturation of cortical pyramidal neurons. Proc Natl Acad Sci U S A 106:7227-7232. CrossRef Medline

Corcoran KA, Quirk GJ (2007) Activity in prelimbic cortex is necessary for the expression of learned, but not innate, fears. J Neurosci 27:840-844. CrossRef Medline

Covington HE 3rd, Lobo MK, Maze I, Vialou V, Hyman JM, Zaman S, LaPlant Q, Mouzon E, Ghose S, Tamminga CA, Neve RL, Deisseroth K, Nestler EJ (2010) Antidepressant effect of optogenetic stimulation of the medial prefrontal cortex. J Neurosci 30:16082-16090. CrossRef Medline

Dadomo H, Sanghez V, Di Cristo L, Lori A, Ceresini G, Malinge I, Parmigiani S, Palanza P, Sheardown M, Bartolomucci A (2011) Vulnerability to chronic subordination stress-induced depression-like disorders in adult 129SvEv male mice. Prog Neuropsychopharmacol Biol Psychiatry 35: 1461-1471. CrossRef Medline

Drew MR, Denny CA, Hen R (2010) Arrest of adult hippocampal neurogenesis in mice impairs single- but not multiple-trial contextual fear conditioning. Behav Neurosci 124:446-454. CrossRef Medline

Farrell MR, Sayed JA, Underwood AR, Wellman CL (2010) Lesion of infralimbic cortex occludes stress effects on retrieval of extinction but not fear conditioning. Neurobiol Learn Mem 94:240-246. CrossRef Medline

Franklin TB, Linder N, Russig H, Thöny B, Mansuy IM (2011) Influence of early stress on social abilities and serotonergic functions across generations in mice. PLoS One 6:e21842. CrossRef Medline

Frodl T, Koutsouleris N, Bottlender R, Born C, Jäger M, Mörgenthaler M, Scheuerecker J, Zill P, Baghai T, Schüle C, Rupprecht R, Bondy B, Reiser M, Möller HJ, Meisenzahl EM (2008) Reduced gray matter brain volumes are associated with variants of the serotonin transporter gene in major depression. Mol Psychiatry 13:1093-1101. CrossRef Medline

Frye CA, Petralia SM, Rhodes ME (2000) Estrous cycle and sex differences in performance on anxiety tasks coincide with increases in hippocampal progesterone and 3alpha,5alpha-THP. Pharmacol Biochem Behav 67: 587-596. CrossRef Medline

Fujioka T, Fujioka A, Duman RS (2004) Activation of cAMP signaling facilitates the morphological maturation of newborn neurons in adult hippocampus. J Neurosci 24:319-328. CrossRef Medline

Gaspar P, Cases O, Maroteaux L (2003) The developmental role of serotonin: news from mouse molecular genetics. Nat Rev Neurosci 4:10021012. CrossRef Medline 
Gilmartin MR, McEchron MD (2005) Single neurons in the medial prefrontal cortex of the rat exhibit tonic and phasic coding during trace fear conditioning. Behav Neurosci 119:1496-1510. CrossRef Medline

Goldwater DS, Pavlides C, Hunter RG, Bloss EB, Hof PR, McEwen BS, Morrison JH (2009) Structural and functional alterations to rat medial prefrontal cortex following chronic restraint stress and recovery. Neuroscience 164:798808. CrossRef Medline

Goodfellow NM, Benekareddy M, Vaidya VA, Lambe EK (2009) Layer II/III of the prefrontal cortex: inhibition by the serotonin 5-HT1A receptor in development and stress. J Neurosci 29:10094-10103. CrossRef Medline

Goodfellow NM, Sargin D, Ansorge MS, Gingrich JA, Lambe EK (2014) Mice with compromised 5-HTT function lack phosphotyrosinemediated inhibitory control over prefrontal 5-HT responses. J Neurosci 34:6107-6111. CrossRef Medline

Gouveia A Jr, dos Santos UD, Felisbino FE, de Afonseca TL, Antunes G, Morato S (2004) Influence of the estrous cycle on the behavior of rats in the elevated T-maze. Behav Processes 67:167-171. CrossRef Medline

Gross C, Zhuang X, Stark K, Ramboz S, Oosting R, Kirby L, Santarelli L, Beck S, Hen R (2002) Serotonin1A receptor acts during development to establish normal anxiety-like behaviour in the adult. Nature 416:396-400. CrossRef Medline

Heinz A, Braus DF, Smolka MN, Wrase J, Puls I, Hermann D, Klein S, Grüsser SM, Flor H, Schumann G, Mann K, Büchel C (2005) Amygdalaprefrontal coupling depends on a genetic variation of the serotonin transporter. Nat Neurosci 8:20-21. CrossRef Medline

Hofer MA, Shair H (1978) Ultrasonic vocalization during social interaction and isolation in 2-week-old rats. Dev Psychobiol 11:495-504. CrossRef Medline

Hohmann CF, Hamon R, Batshaw ML, Coyle JT (1988) Transient postnatal elevation of serotonin levels in mouse neocortex. Brain Res 471:163-166. Medline

Holick KA, Lee DC, Hen R, Dulawa SC (2008) Behavioral effects of chronic fluoxetine in $\mathrm{BALB} / \mathrm{cJ}$ mice do not require adult hippocampal neurogenesis or the serotonin 1A receptor. Neuropsychopharmacology 33:406417. CrossRef Medline

Homberg JR, Schubert D, Gaspar P (2010) New perspectives on the neurodevelopmental effects of SSRIs. Trends Pharmacol Sci 31:60-65. CrossRef Medline

Iñiguez SD, Warren BL, Bolaños-Guzmán CA (2010) Short- and long-term functional consequences of fluoxetine exposure during adolescence in male rats. Biol Psychiatry 67:1057-1066. CrossRef Medline

Izquierdo A, Wellman CL, Holmes A (2006) Brief uncontrollable stress causes dendritic retraction in infralimbic cortex and resistance to fear extinction in mice. J Neurosci 26:5733-5738. CrossRef Medline

Karpova NN, Lindholm J, Pruunsild P, Timmusk T, Castrén E (2009) Longlasting behavioural and molecular alterations induced by early postnatal fluoxetine exposure are restored by chronic fluoxetine treatment in adult mice. Eur Neuropsychopharmacol 19:97-108. CrossRef Medline

Kendler KS, Neale MC, Kessler RC, Heath AC, Eaves LJ (1992) Major depression and generalized anxiety disorder. Same genes, (partly) different environments? Arch Gen Psychiatry 49:716-722. CrossRef Medline

Kilpatrick DG, Koenen KC, Ruggiero KJ, Acierno R, Galea S, Resnick HS, Roitzsch J, Boyle J, Gelernter J (2007) The serotonin transporter genotype and social support and moderation of posttraumatic stress disorder and depression in hurricane-exposed adults. Am J Psychiatry 164:16931699. CrossRef Medline

Kiyasova V, Gaspar P (2011) Development of raphe serotonin neurons from specification to guidance. Eur J Neurosci 34:1553-1562. CrossRef Medline

Kobiella A, Reimold M, Ulshöfer DE, Ikonomidou VN, Vollmert C, Vollstädt-Klein S, Rietschel M, Reischl G, Heinz A, Smolka MN (2011) How the serotonin transporter 5-HTTLPR polymorphism influences amygdala function: the roles of in vivo serotonin transporter expression and amygdala structure. Transl Psychiatry 1:e37. CrossRef Medline

Kuhn CM, Schanberg SM (1998) Responses to maternal separation: mechanisms and mediators. Int J Dev Neurosci 16:261-270. CrossRef Medline

Lee HJ, Lee MS, Kang RH, Kim H, Kim SD, Kee BS, Kim YH, Kim YK, Kim JB, Yeon BK, Oh KS, Oh BH, Yoon JS, Lee C, Jung HY, Chee IS, Paik IH (2005) Influence of the serotonin transporter promoter gene polymorphism on susceptibility to posttraumatic stress disorder. Depress Anxiety 21:135-139. CrossRef Medline
Lee MHS, Williams DI (1974) Changes in licking behaviour of rat mother following handling of young. Anim Behav 22:679-681. CrossRef

Lemogne C, Gorwood P, Boni C, Pessiglione M, Lehéricy S, Fossati P (2011) Cognitive appraisal and life stress moderate the effects of the 5-HTTLPR polymorphism on amygdala reactivity. Hum Brain Mapp 32:1856-1867. CrossRef Medline

Leventopoulos M, Russig H, Feldon J, Pryce CR, Opacka-Juffry J (2009) Early deprivation leads to long-term reductions in motivation for reward and 5-HT1A binding and both effects are reversed by fluoxetine. Neuropharmacology 56:692-701. CrossRef Medline

Lidov HG, Molliver ME (1982a) Immunohistochemical study of the development of serotonergic neurons in the rat CNS. Brain Res Bull 9:559604. CrossRef Medline

Lidov HG, Molliver ME (1982b) An immunohistochemical study of serotonin neuron development in the rat: ascending pathways and terminal fields. Brain Res Bull 8:389-430. CrossRef Medline

Liston C, Miller MM, Goldwater DS, Radley JJ, Rocher AB, Hof PR, Morrison JH, McEwen BS (2006) Stress-induced alterations in prefrontal cortical dendritic morphology predict selective impairments in perceptual attentional set-shifting. J Neurosci 26:7870-7874. CrossRef Medline

Liu D, Diorio J, Tannenbaum B, Caldji C, Francis D, Freedman A, Sharma S, Pearson D, Plotsky PM, Meaney MJ (1997) Maternal care, hippocampal glucocorticoid receptors, and hypothalamic-pituitary-adrenal responses to stress. Science 277:1659-1662. CrossRef Medline

Lo Iacono L, Gross C (2008) Alpha- $\mathrm{Ca}^{2+} /$ calmodulin-dependent protein kinase II contributes to the developmental programming of anxiety in serotonin receptor 1A knock-out mice. J Neurosci 28:6250-6257. CrossRef Medline

Lupien SJ, McEwen BS, Gunnar MR, Heim C (2009) Effects of stress throughout the lifespan on the brain, behaviour and cognition. Nat Rev Neurosci 10:434-445. CrossRef Medline

Marcondes FK, Miguel KJ, Melo LL, Spadari-Bratfisch RC (2001) Estrous cycle influences the response of female rats in the elevated plus-maze test. Physiol Behav 74:435-440. CrossRef Medline

Mayberg HS (2003) Modulating dysfunctional limbic-cortical circuits in depression: towards development of brain-based algorithms for diagnosis and optimised treatment. Br Med Bull 65:193-207. CrossRef Medline

Mayberg HS, Liotti M, Brannan SK, McGinnis S, Mahurin RK, Jerabek PA, Silva JA, Tekell JL, Martin CC, Lancaster JL, Fox PT (1999) Reciprocal limbic-cortical function and negative mood: converging PET findings in depression and normal sadness. Am J Psychiatry 156:675-682. Medline

Mayberg HS, Lozano AM, Voon V, McNeely HE, Seminowicz D, Hamani C, Schwalb JM, Kennedy SH (2005) Deep brain stimulation for treatmentresistant depression. Neuron 45:651-660. CrossRef Medline

Mcdonald AJ, Mascagni F, Guo L (1996) Projections of the medial and lateral prefrontal cortices to the amygdala: a Phaseolus vulgaris leucoagglutinin study in the rat. Neuroscience 71:55-75. CrossRef Medline

Milad MR, Quirk GJ (2002) Neurons in medial prefrontal cortex signal memory for fear extinction. Nature 420:70-74. CrossRef Medline

Moffitt TE, Caspi A, Harrington H, Milne BJ, Melchior M, Goldberg D, Poulton R (2007) Generalized anxiety disorder and depression: childhood risk factors in a birth cohort followed to age 32. Psychol Med 37: 441-452. CrossRef Medline

Mokler DJ, Torres OI, Galler JR, Morgane PJ (2007) Stress-induced changes in extracellular dopamine and serotonin in the medial prefrontal cortex and dorsal hippocampus of prenatally malnourished rats. Brain Res 1148: 226-233. CrossRef Medline

Murmu MS, Salomon S, Biala Y, Weinstock M, Braun K, Bock J (2006) Changes of spine density and dendritic complexity in the prefrontal cortex in offspring of mothers exposed to stress during pregnancy. Eur J Neurosci 24:1477-1487. CrossRef Medline

Mychasiuk R, Gibb R, Kolb B (2012) Prenatal stress alters dendritic morphology and synaptic connectivity in the prefrontal cortex and hippocampus of developing offspring. Synapse 66:308-314. CrossRef Medline

Norcross M, Mathur P, Enoch AJ, Karlsson RM, Brigman JL, Cameron HA, Harvey-White J, Holmes A (2008) Effects of adolescent fluoxetine treatment on fear-, anxiety- or stress-related behaviors in C57BL/6J or BALB/cJ mice. Psychopharmacology (Berl) 200:413-424. CrossRef Medline

Oberlander TF, Gingrich JA, Ansorge MS (2009) Sustained neurobehavioral effects of exposure to SSRI antidepressants during development: 
molecular to clinical evidence. Clin Pharmacol Ther 86:672-677. CrossRef Medline

Ohta K, Miki T, Warita K, Suzuki S, Kusaka T, Yakura T, Liu JQ, Tamai M, Takeuchi Y (2014) Prolonged maternal separation disturbs the serotonergic system during early brain development. Int J Dev Neurosci 33:15-21. CrossRef Medline

Paré D, Smith Y (1993) The intercalated cell masses project to the central and medial nuclei of the amygdala in cats. Neuroscience 57:1077-1090. CrossRef Medline

Parker G, Wilhelm K, Mitchell P, Austin MP, Roussos J, Gladstone G (1999) The influence of anxiety as a risk to early onset major depression. J Affect Disord 52:11-17. CrossRef Medline

Peters J, Kalivas PW, Quirk GJ (2009) Extinction circuits for fear and addiction overlap in prefrontal cortex. Learn Mem 16:279-288. CrossRef Medline

Pezawas L, Meyer-Lindenberg A, Drabant EM, Verchinski BA, Munoz KE, Kolachana BS, Egan MF, Mattay VS, Hariri AR, Weinberger DR (2005) 5-HTTLPR polymorphism impacts human cingulate-amygdala interactions: a genetic susceptibility mechanism for depression. Nat Neurosci 8:828-834. CrossRef Medline

Price JL, Drevets WC (2010) Neurocircuitry of mood disorders. Neuropsychopharmacology 35:192-216. CrossRef Medline

Quirk GJ, Mueller D (2008) Neural mechanisms of extinction learning and retrieval. Neuropsychopharmacology 33:56-72. CrossRef Medline

Quirk GJ, Garcia R, González-Lima F (2006) Prefrontal mechanisms in extinction of conditioned fear. Biol Psychiatry 60:337-343. CrossRef Medline

Rabinak CA, Zimmerman JM, Chang CH, Orsini CA (2008) Bidirectional changes in the intrinsic excitability of infralimbic neurons reflect a possible regulatory role in the acquisition and extinction of pavlovian conditioned fear. J Neurosci 28:7245-7247. CrossRef Medline

Radley JJ, Rocher AB, Janssen WG, Hof PR, McEwen BS, Morrison JH (2005) Reversibility of apical dendritic retraction in the rat medial prefrontal cortex following repeated stress. Exp Neurol 196:199-203. CrossRef Medline

Rentesi G, Antoniou K, Marselos M, Syrrou M, Papadopoulou-Daifoti Z, Konstandi M (2013) Early maternal deprivation-induced modifications in the neurobiological, neurochemical and behavioral profile of adult rats. Behav Brain Res 244:29-37. CrossRef Medline

Richardson-Jones JW, Craige CP, Nguyen TH, Kung HF, Gardier AM, Dranovsky A, David DJ, Guiard BP, Beck SG, Hen R, Leonardo ED (2011) Serotonin-1A autoreceptors are necessary and sufficient for the normal formation of circuits underlying innate anxiety. J Neurosci 31:60086018. CrossRef Medline

Rodgers RJ, Boullier E, Chatzimichalaki P, Cooper GD, Shorten A (2002) Contrasting phenotypes of C57BL/6JOlaHsd, 129S2/SvHsd and 129/SvEv mice in two exploration-based tests of anxiety-related behaviour. Physiol Behav 77:301-310. CrossRef Medline

Roiser JP, de Martino B, Tan GC, Kumaran D, Seymour B, Wood NW, Dolan RJ (2009) A genetically mediated bias in decision making driven by failure of amygdala control. J Neurosci 29:5985-5991. CrossRef Medline

Rosenberg KM, Denenberg VH, Zarrow MX (1970) Mice (Mus musculus) reared with rat aunts: the role of rat-mouse contact in mediating behavioural and physiological changes in the mouse. Anim Behav 18:138-143. CrossRef Medline

Rosoklija GB, Petrushevski VM, Stankov A, Dika A, Jakovski Z, Pavlovski G, Davcheva N, Lipkin R, Schnieder T, Scobie K, Duma A, Dwork AJ (2014) Reliable and durable Golgi staining of brain tissue from human autopsies and experimental animals. J Neurosci Methods 230:20-29. CrossRef Medline

Royer S, Martina M, Paré D (1999) An inhibitory interface gates impulse traffic between the input and output stations of the amygdala. J Neurosci 19:10575-10583. Medline

Santini E, Porter JT (2010) M-type potassium channels modulate the intrinsic excitability of infralimbic neurons and regulate fear expression and extinction. J Neurosci 30:12379-12386. CrossRef Medline
Santini E, Quirk GJ, Porter JT (2008) Fear conditioning and extinction differentially modify the intrinsic excitability of infralimbic neurons. J Neurosci 28:4028-4036. CrossRef Medline

Scobie KN, Hall BJ, Wilke SA, Klemenhagen KC, Fujii-Kuriyama Y, Ghosh A, Hen R, Sahay A (2009) Kruppel-like factor 9 is necessary for late-phase neuronal maturation in the developing dentate gyrus and during adult hippocampal neurogenesis. J Neurosci 29:9875-9887. CrossRef Medline

Shah MP, Wang F, Kalmar JH, Chepenik LG, Tie K, Pittman B, Jones MM, Constable RT, Gelernter J, Blumberg HP (2009) Role of variation in the serotonin transporter protein gene (SLC6A4) in trait disturbances in the ventral anterior cingulate in bipolar disorder. Neuropsychopharmacology 34:1301-1310. CrossRef Medline

Sholl DA (1953) Dendritic organization in the neurons of the visual and motor cortices of the cat. J Anat 87:387-406. Medline

Sierra-Mercado D Jr, Corcoran KA, Lebrón-Milad K, Quirk GJ (2006) Inactivation of the ventromedial prefrontal cortex reduces expression of conditioned fear and impairs subsequent recall of extinction. Eur J Neurosci 24:1751-1758. CrossRef Medline

Sierra-Mercado D, Padilla-Coreano N, Quirk GJ (2011) Dissociable roles of prelimbic and infralimbic cortices, ventral hippocampus, and basolateral amygdala in the expression and extinction of conditioned fear. Neuropsychopharmacology 36:529-538. CrossRef Medline

Smit-Rigter LA, Wadman WJ, van Hooft JA (2011) Alterations in apical dendrite bundling in the somatosensory cortex of 5-HT(3A) receptor knockout mice. Front Neuroanat 5:64. CrossRef Medline

Smit-Rigter LA, Noorlander CW, von Oerthel L, Chameau P, Smidt MP, van Hooft JA (2012) Prenatal fluoxetine exposure induces life-long serotonin 5-HT(3) receptor-dependent cortical abnormalities and anxietylike behaviour. Neuropharmacology 62:865-870. CrossRef Medline

Vidal-Gonzalez I, Vidal-Gonzalez B, Rauch SL, Quirk GJ (2006) Microstimulation reveals opposing influences of prelimbic and infralimbic cortex on the expression of conditioned fear. Learn Mem 13:728-733. CrossRef Medline

Vinkers CH, Oosting RS, van Bogaert MJ, Olivier B, Groenink L (2010) Early-life blockade of 5-HT(1A) receptors alters adult anxiety behavior and benzodiazepine sensitivity. Biol Psychiatry 67:309-316. CrossRef Medline

Vitalis T, Ansorge MS, Dayer AG (2013) Serotonin homeostasis and serotonin receptors as actors of cortical construction: special attention to the 5-HT3A and 5-HT6 receptor subtypes. Front Cell Neurosci 7:93. CrossRef Medline

Vogel G, Neill D, Hagler M, Kors D (1990) A new animal model of endogenous depression: a summary of present findings. Neurosci Biobehav Rev 14:85-91. CrossRef Medline

Wang M, Perova Z, Arenkiel BR, Li B (2014) Synaptic modifications in the medial prefrontal cortex in susceptibility and resilience to stress. J Neurosci 34:7485-7492. CrossRef Medline

Warden MR, Selimbeyoglu A, Mirzabekov JJ, Lo M, Thompson KR, Kim SY, Adhikari A, Tye KM, Frank LM, Deisseroth K (2012) A prefrontal cortex-brainstem neuronal projection that controls response to behavioural challenge. Nature 492:428-432. CrossRef Medline

Weissman MM, Wickramaratne P, Nomura Y, Warner V, Verdeli H, Pilowsky DJ, Grillon C, Bruder G (2005) Families at high and low risk for depression: a 3-generation study. Arch Gen Psychiatry 62:29-36. CrossRef Medline

Wellman CL, Izquierdo A, Garrett JE, Martin KP, Carroll J, Millstein R, Lesch KP, Murphy DL, Holmes A (2007) Impaired stress-coping and fear extinction and abnormal corticolimbic morphology in serotonin transporter knock-out mice. J Neurosci 27:684-691. CrossRef Medline

Yu Q, Teixeira CM, Mahadevia D, Huang Y, Balsam D, Mann JJ, Gingrich JA, Ansorge MS (2014) Dopamine and serotonin signaling during two sensitive developmental periods differentially impact adult aggressive and affective behaviors in mice. Mol Psychiatry 19:688-698. CrossRef Medline 